\title{
Tax policy and innovation performance: Evidence from enactment of the Alternative Simplified Credit
}

\begin{abstract}
$\underline{\text { Abstract }}$
We examine how direct tax incentives affect firm innovation performance using a new U.S. R\&D tax credit regime enacted in 2007, the Alternative Simplified Credit (ASC). A difference-indifferences analysis indicates that innovation performance is poorer for ASC users than for firms using the original R\&D tax credit method following the ASC enactment. The results are stronger for firms with poorer governance and greater innovation diversity. ASC users suffer from poorer profitability and lower valuations. The findings remain robust to self-selection bias and various robustness checks. Our evidence favors a dark-side view of R\&D tax credit effects under the ASC.
\end{abstract}

JEL classification: G30; G38; O38.

Keywords: R\&D tax credits; Alternative Simplified Credit; Innovation performance; Innovation diversity; Corporate governance. 


\section{Tax policy and innovation performance: Evidence from enactment of the Alternative Simplified Credit}

The U.S. tax code provides incentives to promote corporate investment that allows firms to gain competitive advantages in global markets. To examine the effectiveness of tax policy as to its impact on corporate intangible investment, researchers have focused mainly on research and development (R\&D) tax credits, which provide more direct tax incentives than general corporate tax policies. These are perhaps the most visible tax incentives related to technology (see, e.g., Mansfield, 1986; Hall and Van Reenen, 2000). Mansfield (1986), Bloom, Griffith, and Van Reenen (2002), Wilson (2009), Finley, Lusch, and Cook (2015), and Rao (2016) have documented that U.S. R\&D tax credits reduce R\&D costs and have a positive effect on firm R\&D expenditures, suggesting that a favorable tax policy encourages corporate intangible investment. ${ }^{1}$ Tax policy also has effects on corporate tangible investment. Hall and Jorgenson (1967), Summers et al. (1981), and others show that favorable U.S. tax policies stimulate firm capital expenditures by reducing investment costs. ${ }^{2}$

While prior studies suggest that U.S. R\&D tax credits stimulate firm innovation inputs (i.e., R\&D expenditures), how they affect firm innovation output performance has so far received limited attention. As indicated by Hall, Jaffe, and Trajtenberg (2001, 2005) and Hsu (2009), there is a variation in the innovation performance produced by an $R \& D$ expenditure. The government cares more about firm $R \& D$ output performance than it does about firm $R \& D$ expenditures when it evaluates the effects of R\&D tax credit policy (Jaffe, 2000). This is because R\&D expenditures do not necessarily create positive economic value. The expenditures may in

\footnotetext{
${ }^{1}$ Mukherjee, Singh, and Žaldokas (2017) examine general tax policies, which include changes in corporate tax rates and other changes that affect the tax bill (e.g., reduction in income tax deductibility). They show that a reduction in corporate tax rates has a weak but positive effect on firm innovation. Their finding is further confirmed by Atanassov and Liu (2019).

${ }^{2}$ For an excellent review, see Hanlon and Heitzman (2010).
} 
fact have a negative economic impact if the $R \& D$ investment is wasteful or produces outputs that perform poorly.

We examine how U.S. R\&D tax credits affect firm innovation performance using a new federal R\&D tax credit regime, the Alternative Simplified Credit (ASC), made effective in 2007. Prior to enactment of the ASC, all firms that qualified as R\&D tax credit users applied for tax credits within one $\mathrm{R} \& \mathrm{D}$ tax regime under the Omnibus Budget Reconciliation Act tax credit (OBRA credit). The OBRA credit was complex and not friendly to innovative firms. ${ }^{3}$ The ASC regime did not replace the OBRA credit, but rather became part of a dual-track system. Firms could choose between two credit-calculation methods, depending on which method provided a better tax credit, but a switch to the ASC regime is not reversible.

The ASC regime can have positive or negative effects on the performance of firm innovation outputs. The bright-side view argues that the ASC leads to better innovation performance. As R\&D tax credits motivate firm investment in R\&D and the ASC simplifies their application, there is likely to be more R\&D investment (Finley, Lusch, and Cook, 2015). When the level of innovation inputs (i.e., R\&D expenditures) is higher, use of the ASC is likely to enhance firm innovation output performance (e.g., Aghion, Van Reenen, and Zingales, 2013; Hsu, Tian, and $\mathrm{Xu}, 2014)$.

The dark-side view, on the other hand, argues that the ASC has a negative effect on innovation performance because of the agency problem of free cash flow and internal capital market inefficiency. Jensen $(1986,1993)$ defines free cash flow as the cash flow remaining after a firm has invested in all positive net present value (NPV) projects, where free cash flow is an inverse function of tax payments (e.g., Lehn and Poulsen, 1989; Lang, Stulz, and Walkling,

\footnotetext{
${ }^{3}$ Industries generally regard the ASC as a friendlier R\&D tax credit regime (see the report of IPC-Association Connecting Electronics Industries at https://www.ipc.org/ContentPage.aspx?pageid=Alternative-Simplified-CreditComputation).
} 
1991). As firms using the ASC method gain extra tax benefits, they will, all else equal, pay less tax and generate more free cash flow. Thus, ASC firms are likely to face higher internal capital market inefficiency, which arises from conflicts among internal innovation teams and the misallocation of extra resources. This is consistent with the argument of Holmstrom (1989) that innovation activities may mix poorly with relatively routine activities in an organization, a notion confirmed by Henderson and Cockburn (1996), Sampson (2007), and Barnes, Lynham, Kalberg and Leung (2016). Higher internal capital market inefficiency in ASC firms can diminish effort paid to uncertain $R \& D$ projects, and adversely affect the performance of innovation outputs (Seru, 2014).

To examine the impact of the ASC since 2007, we collect a sample of U.S. firms between 2003 and 2010 and identify them as either ASC or OBRA users according to federal tax laws, Internal Revenue Code (IRC) Section 41. Our sample ends in 2010 to alleviate the patent truncation issue noted by Hall, Jaffe, and Trajtenberg (2001, 2005). We use a difference-in-differences approach and investigate the change in innovation performance since 2007 between firms switching from the OBRA to the ASC method and firms continuing with the OBRA. If a firm gains an R\&D tax credit through the OBRA before 2007 and shifts to the ASC in any year between 2007 and 2010, we identify it as an ASC user. If a firm stays in the OBRA regime in both pre- and post-2007 periods, we identify it as an OBRA user. We proxy for the performance of innovation by citations per patent and number of patents, two common measures used by prior researchers (e.g., Belenzon and Berkovitz, 2010; Aghion, Van Reenen, and Zingales, 2013; He and Tian, 2013; Hirshleifer, Hsu, and Li, 2013; Hsu, Tian, and Xu, 2014).

We find that, relative to OBRA users, ASC users show a significant decline in citations per patent and numbers of patents after enactment of the Alternative Simplified Credit. The impact 
of ASC is also economically significant. Firms switching from the OBRA to the ASC experience a decline in citations per patent (numbers of patents) of about $23.1 \%(22.8 \%)$ surrounding the switching year compared to firms staying with OBRA. The results indicate that the ASC method results in poorer performance of corporate innovation outputs, hence favoring the dark-side rather than the bright-side view of the effects of R\&D tax credits. As choice of the R\&D tax credit method is voluntary, we also perform a Heckman (1979) two-stage regression analysis to control for potential self-selection bias. The results remain unchanged. The findings are also robust when we use a sample limited to firms that identify themselves in their $10-\mathrm{K}$ reports as R\&D tax credit users, or a propensity score matched sample, or alternative measures of innovation performance (generality, originality, relative citations, self-citations, non-selfcitations, and aggregate citations).

We carry out two conditional tests to examine the strength of the reduction in patent counts and citations per patent of the ASC users. ASC is expected to have a more negative impact on innovation performance for firms with poorer corporate governance. Hoechle et al. (2012) suggest that corporate governance explains a considerable amount of internal capital market efficiency. Hence, when ASC users are not well governed, inefficiency in internal capital markets resulting from the ASC method is higher. We also expect a more negative effect of ASC on innovation performance when a firm has more diversified innovation activities. As innovation diversity may lead to resource misallocation and agency costs (Holmstrom, 1989), firms with greater innovation diversity are subject to poorer internal market efficiency. When firms with more diversified innovation activities are less efficient in allocating the extra resources from the additional free cash flows of the ASC tax benefit to different innovation teams, they are likely to suffer greater deterioration in innovation performance. Consistent with our predictions, we find 
stronger negative effects of ASC on innovation performance when firms have poorer governance or face higher levels of innovation diversification.

Results of a number of additional tests corroborate our findings. If a firm adopting the ASC method experiences poorer innovation performance than OBRA users, its operating performance and valuation are likely to decline. We find supporting evidence by documenting that ASC users experience poorer profitability and lower valuations than OBRA users after enactment of the Alternative Simplified Credit.

We also investigate the effect of the Alternative Simplified Credit on young firms. As young firms, with their stronger sales growth, are less likely to qualify for R\&D tax credits under the OBRA method, the ASC method may be advantageous to facilitate their innovation activities. Thus, our difference-in-differences analysis tends to exclude young firms. To address this concern, we compare innovation performance for young firms that do and do not use R\&D tax credits under the ASC method. We show that young firms using the ASC regime perform much the same in innovation as other young firms, suggesting that our conclusion is not likely driven by the exclusion of young firms.

Our results are also not explained by $q$-theory, which proposes that a firm selects investment projects according to their NPV (e.g., Liu, Whited, and Zhang, 2009; Li and Zhang, 2010; Wu, Zhang, and Zhang, 2010). $Q$-theory predicts a more negative impact of the ASC method on innovation performance for firms that have decreasing or constant returns to scale. According to $q$-theory, the marginal revenue of investment declines with the level of investment, and the firm decides its optimal investment when the marginal revenue equals the marginal cost of capital. One important assumption behind $q$-theory is that firm technology is represented by a production function exhibiting decreasing or constant returns to scale (Liu, Whited, and Zhang, 
2009; Wu, Zhang, and Zhang, 2010). Thus, ASC users are expected to show poorer innovation performance than OBRA users in the post-ASC period, and this relation is stronger for ASC users with decreasing or constant returns to scale than for ASC users with increasing returns to scale. We do not find, however, any significant difference in the ASC effect on innovation performance between firms with decreasing or constant returns to scale and other firms.

One challenge to our research is that the ASC stimulates R\&D investment, and probably leads to technology dispersion with greater R\&D spillover, which may be beneficial to other firms' innovation activities. ${ }^{4}$ We investigate this issue by performing R\&D spillover regressions using the spillover measure of Jaffe (1986), Bloom, Schankerman, and Van Reenen (2013), and Qiu and Wan (2015). We show that the ASC method does not contribute to more R\&D spillover than the OBRA method, implying that the ASC is not associated with greater technology dispersion.

It is possible that, when the OBRA regime was first enacted in 1981, R\&D tax credits had produced a negative effect on firm innovation performance. Hence, our results for the ASC regime might be nothing more than reconfirmation of the evidence in a different $R \& D$ tax credit regime. For a sample of U.S. firms between 1974 and 2006, we perform a difference-in-differences analysis by examining whether there are differences in innovation performance changes between OBRA users and firms not taking R\&D tax credits. We find that OBRA users significantly increased both citations per patent and patent counts over other firms following the 1981 Omnibus Budget Reconciliation Act. In contrary to the ASC results that there was a deterioration in innovation performance, the Omnibus Budget Reconciliation Act improves the performance of innovation outputs. Thus, the evidence favors a bright-side view of R\&D tax

\footnotetext{
${ }^{4}$ See, for example, the U.S. Treasury Department report (https://www.treasury.gov/resource-center/tax-policy/tax -analysis/Documents/RE-Credit.pdf).
} 
credit effects under OBRA.

Finally, in a placebo test we examine whether our findings are driven merely by chance. We replace each ASC user with a randomly selected firm from among OBRA users (i.e., pseudo-ASC users) and run regressions of number of citations per patent and number of patents 1,000 times. We show no significant impact of R\&D tax credits on firm innovation performance for these pseudo-ASC users, confirming that our findings are unlikely driven by pure luck.

Our paper makes three valuable contributions to the literature. First, our research provides evidence regarding which and how tax-motivated activities do not necessarily enhance shareholder value. Given a recent stream of studies on the dark-side economic consequences of corporate tax avoidance, this paper helps rationalize why some tax avoidance reduces firm value or increases managerial rent diversion (Lev and Nissim, 2004; Hanlon, 2005; Desai and Dharmapala, 2006; Laplante, Skaife, Swenson, and Wangerin 2019). Second, the conventional theory suggests that government tax policy provides incentives to mitigate $\mathrm{R} \& \mathrm{D}$ underinvestment. Research in this regard focuses mainly on innovation inputs and shows that U.S. R\&D tax credits encourage R\&D expenditures (e.g., Mansfield, 1986; Bloom, Griffith, and Van Reenen, 2002; Wilson, 2009; Finley, Lusch, and Cook, 2015; Rao, 2016). We use a new U.S. federal tax credit that became effective in 2007 as a quasi-experiment, and show that R\&D tax credits lead to a deterioration in the performance of innovation outputs subsequent to establishment of that credit. Third, to the best of our knowledge, this is the first evidence to document the dark-side effect of a government tax policy on firm innovation. Our research calls into question whether the direct tax incentives enacted since 2007 to stimulate corporate R\&D investments create positive economic value for U.S. firms.

Second, a number of studies over the past decade have investigated the determinants of firm 
innovation performance. They find that takeover provisions, liquidity, ownership structure, top-executive compensation, analyst coverage, labor union and law enactment can affect the performance of corporate innovation outputs (e.g., Becker-Blease, 2011; Aghion, Van Reenen, and Zingales, 2013; Ederer and Manso, 2013; He and Tian, 2013; Fang, Tian, and Tice, 2014; Bradley, Kim, and Tian, 2016; Png, 2017). Our research adds to this line of research by documenting that government tax policy offering direct tax incentives through $R \& D$ tax credits also plays an important role in determining innovation performance.

The rest of this paper is organized as follows. Section 1 describes U.S. R\&D tax credit policy. Section 2 explains our data and methodology and provides summary statistics. Section 3 examines the effect of the new $R \& D$ tax credit regime on innovation performance. Section 4 offers conditional tests. Section 5 presents a number of additional analyses. The final section concludes.

\section{U.S. R\&D tax credits}

The first regular R\&D tax credit to be implemented in the U.S. established a statutory tax credit of $25 \%$ under the Omnibus Budget Reconciliation Act of 1981. To earn this R\&D tax credit, a firm must have qualified research expenses (QREs) over a moving average threshold, the average of past three-year qualified research expenses. ${ }^{5}$ In 1986, the U.S. Congress made a significant change in taxes, including $R \& D$ tax credits. The statutory rate for $R \& D$ tax credits was reduced to $20 \%$, and the threshold became a fixed base. The base amount is a firm-specific fixed research intensity (i.e., QREs in gross receipts from 1984 through 1988) multiplied by the minimum of $16 \%$ or prior four-year average gross receipts. As in the 1981 OBRA, the credit retained the 50\% base-amount limitation of the current-year QRE. Further rules in the Omnibus

${ }^{5} \mathrm{R} \& \mathrm{D}$ tax credits and qualified research expenses were then defined in IRC $\S 44 \mathrm{~F}$ (currently IRC $\S 41$ ). 
Budget Reconciliation Act of 1993 were intended to mitigate the problem that some firms did not conduct research during 1984-1988. The base percentage was set at 3\% for firms that had just experienced their first five-year R\&D spending and sales, a slightly higher base determined by their R\&D intensity for the sixth through tenth years, and a fixed base determined by their R\&D intensity thereafter. ${ }^{6}$

Since 2007, a dual-track R\&D tax credit system has been implemented in the U.S. Firms can apply for two alternative $R \& D$ tax credits when they conduct qualified research activities over a certain threshold: regular R\&D tax credits (OBRA) and alternative simplified research credits (ASC). The ASC statutory credit rate was initially set at $12 \%$ in 2007 and has been increased to $14 \%$ since 2009. The ASC retains one feature of the original formula of the regular R\&D tax credits enacted in 1981, using a moving average of the previous three years. The R\&D tax credits in year $t$ based on the OBRA and ASC methods are computed as follows:

$$
\begin{aligned}
& \text { OBRA_Credit } t_{t,>1989}=0.2\left\{Q R E_{t}-\max \left[\left(\frac{1}{4} \sum_{k=1}^{4} \text { Sales }_{t-k}\right) \times \min \left(0.16, \frac{\sum_{j=1984}^{1988} Q R E_{j}}{\sum_{j=1984}^{1988} \text { Sales }_{j}}\right), 0.5 \times Q R E_{t}\right]\right\}, \\
& \text { A S } \underline{C} C r e d \dot{*} t \tau\left\{Q R E-0.5 \times \frac{1}{3} \sum_{k=1}^{3} Q R \underline{E}_{k}\right\},
\end{aligned}
$$

where $Q R E$ is qualified research expenses, Sales are revenues, and $\tau$ is the statutory credit rate $(12 \%$ or $14 \%)$.

The ASC regime is subject to the same drawback as the original formula, in that spending in

\footnotetext{
${ }^{6}$ Under IRC $\S 41$ (a), in general a firm fixed-base percentage is QRE/gross receipts during 1984-1988. R\&D start-ups have a different fixed-base percentage from other firms. For the first five taxable years, the fixed-base percentage is $3 \%$. For the sixth and seventh taxable years, the fixed-base percentage is $1 / 6$ and $1 / 3$ of QRE/gross receipts for the previous two years, respectively. For the eighth through the tenth taxable years, the fixed-base percentage is $1 / 2,2 / 3$, and $5 / 6$ of QRE/gross receipts for the fifth through the seventh, eighth, and ninth years, respectively. Thereafter, the fixed-base percentage is the QRE/gross receipts for any selected five years from the fifth to the tenth years.
} 
one year raises the base amount for the next three years. Yet, some firms may still benefit from the ASC regime, such as start-ups, firms without QRE documentation from 1984 through 1988, or firms with a high base amount or rapidly growing sales. Grigsby and Westmoreland (2001), for example, indicate that the semiconductor industry posted unusually high fixed-base percentages from 1984 through 1988 because Japanese competition produced unusually low sales during the mid-1980s. Another feature of the new R\&D tax credit system is that a firm originally choosing the OBRA method can switch to apply for the ASC method, but it cannot switch back to the OBRA method once it selects the ASC method.

\section{Data and methodology}

\subsection{Data}

The financial and stock market information of our sample firms comes from Compustat and the Center for Research in Security Prices (CRSP) database. We collect U.S. patent data from the European Patent Office (EPO) Worldwide Patent Statistical Database (PATSTAT, 2016 edition) because it provides detailed and comprehensive information (Bena and Li, 2014). We eliminate financial firms (Compustat SIC codes 6000-6999), American depositary receipts, closed-end funds, non-U.S. firms, and real estate investment trusts from the sample. For the difference-in-differences analysis, the sample includes U.S. firms that applied for either the ASC or OBRA credit between 2003 and 2010. The sample period starts in 2003 to mitigate potential confounding effects associated with the Internet bubble and stops at 2010 to ensure that we have enough patent and citation observations for the ASC users after the switching year. Given that more recent patents will have fewer citations, a truncation problem is likely to occur. To address this concern, we use the truncation adjustment process suggested by Hall, Jaffe, and Trajtenberg 
$(2001,2005)$ and terminate our patent and citation data in the year 2014. In our final sample, 569 firms switched from the OBRA to the ASC regime, and 2,825 firms stayed in the OBRA regime between 2007 and 2010 .

\subsection{ASC and OBRA users and innovation performance measures}

Firms might not disclose qualified research expenses (QREs) and R\&D tax credits in annual reports. The computation of R\&D tax credits, however, is based on QREs. According to Hall and van Reenen (2000), about 50\% to $73 \%$ of R\&D expenses are QREs, implying that QREs are highly correlated with $R \& D$ expenditures shown in the income statement. Accordingly, we use $60 \%$ of R\&D expenditures as a proxy for QREs. Our conclusion remains unchanged when QREs are proxied by $50 \%$ or $70 \%$ of R\&D expenditures. ${ }^{7}$ We further assume that firms are motivated by greater tax benefits when they decide to use a $R \& D$ tax credit method. That is, we assume that a firm uses Equations (1) and (2) and chooses to switch to the ASC method if it produces higher R\&D tax credits than under OBRA. Accordingly, a firm is defined as an ASC user if it gains an R\&D tax credit through the OBRA regime before 2007 but shifts to the ASC regime in any year between 2007 and 2010 (i.e., the ASC offers a higher R\&D tax credit). A firm is defined as an OBRA user if it stays in the OBRA regime in both pre- and post-2007 periods.

We use citations per patent and number of patents to measure the performance of firm innovation outputs. Citations are the number of truncation-adjusted citations divided by the number of patents applied for by a firm. Number of patents is the number of patents applied for. Firms that have never applied to the United States Patent and Trademark Office (USPTO) for patents are removed from the sample.

\footnotetext{
${ }^{7}$ Later, we also use a reduced sample of firms that indicate in their $10-\mathrm{K}$ reports they are R\&D tax credit users. While $40 \%$ of our sample firms do not disclose their R\&D tax credit information, this reduced sample shows consistent results.
} 


\subsection{Descriptive statistics}

Table 1 presents descriptive statistics of the ASC and OBRA users. Panel A shows the sample distribution based on Fama-French 48 industry classifications. More than $60 \%$ of sample firms that gain R\&D tax credits come from high-tech and bio-tech related industries (business services, computers, electronic equipment, machinery, measuring and control equipment, medical equipment, and pharmaceutical products). Panel B presents the estimated R\&D tax credits per year under the OBRA and ASC methods. Consistent with our definition, the ASC users gained higher tax credits under ASC than under OBRA, while the OBRA users gained higher tax credits under OBRA than under ASC. The incremental tax benefit for the ASC users was $\$ 3.818(=13.268-9.450)$ million per year, which represents about $17.4 \%$ of median $\mathrm{R} \& \mathrm{D}$ expenditures and is about $40.4 \%$ higher than the R\&D tax benefit obtained under OBRA. The incremental tax benefit for the OBRA users is only $\$ 0.786(=7.052-6.266)$ million per year, much lower than that for the ASC users.

\section{Insert Table 1 around here}

Panel C presents descriptive statistics of firm characteristics in 2006, the year prior to enactment of the Alternative Simplified Credit. $R \& D$ expenditures are the dollar amount of $\mathrm{R} \& \mathrm{D}$ expenditures (in millions); Size is book assets (in millions); R\&D-to-assets ratio is $\mathrm{R} \& \mathrm{D}$ expenditures divided by book assets; Cash-to-assets ratio is cash divided by book assets; Leverage is long-term debt divided by common equity; $R O A$ is earnings before extraordinary items divided by book assets; $M / B$ is the market value of common equity divided by the book value of common equity; and $K / L$ is property, plant, and equipment (PPE) divided by number of employees. Prior to the ASC enactment, the ASC users had higher patent citations and patent counts and spent more on R\&D expenditures than the OBRA users. The ASC users also tended 
to be larger and to have lower R\&D-to-assets and cash-to-assets ratios, higher leverage, and better return on assets.

\section{Effects of R\&D tax credits on innovation performance}

\subsection{Multivariate analysis}

We perform regression analysis of innovation performance using firms adopting the OBRA or ASC method:

$$
\begin{aligned}
& {\text { (Innovation performance })_{i, t}} \\
& =a_{0}+a_{1}\left(D \text { u m mfyo } \mathrm{s} \text { witc } h \text { ifri g } m_{i} s+a_{2}\left(D \text { u m mfyo po o sA } S G_{t}\right.\right. \\
& \left.\quad+a_{3} \text { (Dummy for switching firms }\right)_{i} \times(\text { Dummy for post } A S C)_{t}+\gamma^{\prime} \boldsymbol{X}_{i, t}+\theta_{j}+e_{i, t} \text {. }
\end{aligned}
$$

The dependent variable, Innovation performance, refers to the two measures of firm innovation performance, Citations and Number of patents, over the period from 2003 through 2014. Dummy for switching firms is equal to one for an ASC user and zero for an OBRA user. Dummy for post $A S C$ is equal to one for the years after 2006, and zero otherwise. The effect of difference-in-differences is measured by the interaction variable, Dummy for switching firms $\times$ Dummy for post ASC, which captures the change in innovation performance for the ASC users (the treatment group) after enactment of the Alternative Simplified Credit relative to the OBRA users (the control group). $\boldsymbol{X}$ represents a set of control variables suggested in the literature, including $R \& D$-to-assets ratio, $\log ($ Size $)$, Cash-to-assets ratio, Leverage, $R O A, M / B$, and $K / L$ (e.g., Aghion, Van Reenen, and Zingales, 2013; He and Tian, 2013; Chang et al., 2015). ${ }^{8} \theta$

\footnotetext{
8 The results are similar when we winsorize all control variables at the 1st and 99th percentiles. Our conclusion also remains unchanged if we additionally control for Analyst coverage, Institutional ownership, CEO turnover, CEO turnover $\times$ Dummy for post ASC, and $R \& D$-to-assets ratio $\times$ Dummy for post ASC, although the sample size is substantially reduced. Analyst coverage is number of analysts following the firm, where data come from the IBES database. Institutional ownership is percentage of shares held by institutional investors, where data come from the
} 
captures Fama-French 48 industry fixed effects. We compute $t$-statistics using standard errors that are clustered by firm.

Table 2 presents the regression results, where Models 1 and 2 use the logarithm of one plus citations per patent and the logarithm of one plus number of patents as the dependent variable, respectively. The coefficients on the interaction variable, Dummy for switching firms $\times$ Dummy for post ASC, are -0.2308 and -0.2276 for Citations and Number of patents, respectively, both statistically significant at the $1 \%$ level. These coefficients indicate that, compared to firms staying in the OBRA regime, firms switching from the OBRA regime to the ASC regime experienced a decline in citations per patent and numbers of patents of about $23.1 \%$ and $22.8 \%$ surrounding the switching year, respectively. Thus, we see poorer innovation performance from the ASC users after enactment of the Alternative Simplified Credit than from the OBRA users. This evidence favors a negative interpretation of the effect of $R \& D$ tax credits on innovation performance. ${ }^{9}$

\section{$\underline{\text { Insert Table } 2 \text { around here }}$}

We also perform difference-in-differences analysis of $R \& D$ expenditures and present the results in Internet Appendix Table A1. Following Finley, Lusch, and Cook (2015), we perform dynamic panel regressions of the logarithm of one plus R\&D expenses on Dummy for switching firms, Dummy for post ASC, Dummy for switching firms $\times$ Dummy for post ASC, and a set of

Thomson Reuters 13F database. CEO turnover is a dummy that is equal to one if a CEO is replaced by a new one, where data come from the S\&P ExecuComp database.

9 We perform several robustness checks of model specifications, including Tobit regressions, Poisson regressions, and negative binomial regressions. We also use one-year-ahead patent or three-year cumulative patent measures as the dependent variable. All results are consistent with the findings so far. We further redefine ASC/OBRA users using the average of tax credits in the current year and the estimated tax credits from Equations (1) and (2) during the following three years based on average R\&D growth and average sales growth over the past five years. Firms are defined as ASC users if they gain OBRA credits before 2007 but shift to the ASC regime in any year between 2007 and 2010 (i.e., the ASC offers a higher forward-looking R\&D tax credit). While this alternative approach may suffer from a look-ahead bias, our conclusion remains valid. 
control variables for the sample periods from 2003 through 2010 and from 2005 through $2008 .^{10}$ Coefficients are estimated using a system generalized method of moments (GMM) approach. The coefficients on Dummy for switching firms $\times$ Dummy for post ASC are significantly positive at the $10 \%$ level or better in both sample periods. Thus, the results show that enactment of the Alternative Simplified Credit encourages firm R\&D investments, consistent with prior research that indicates $R \& D$ tax credits have a positive impact on firm innovation inputs.

\subsection{Self-selection bias}

According to U.S. federal tax law, an OBRA tax user could choose to use the ASC method since 2007, but cannot switch back to the OBRA method once selecting the ASC method. As a firm's choice of the tax credit method is voluntary, our estimates in Equation (3) could be subject to a self-selection bias. To control for this potential bias, we perform Heckman's (1979) two-stage regression analysis. In the first stage, we use a probit regression of Dummy for switching firms on IRS attention, Size, Cash-to-assets ratio, Leverage, Sales growth, K/L, Average cash effective tax rates, and Volatility of cash effective tax rates. IRS attention is a dummy variable that is equal to one for a firm with tax positions that incurred penalties, were increased, or were settled with the Internal Revenue Service (IRS) during the year. Sales growth is this year's sales minus previous year's sales divided by previous year's sales. Average cash effective tax rates are the average of cash effective tax rates over the past three years, where the cash effective tax rate is equal to cash taxes paid divided by pre-tax earnings before special items. Volatility of cash effective tax rates is the standard deviation of cash effective tax rates over the past three years. Other variables have been defined.

We expect IRS attention to be positively related to the likelihood that a firm will switch to

10 The results are similar for the entire sample period from 2005 through 2014. 
the ASC regime. In 2006, the Financial Accounting Standards Board (FASB) introduced FIN 48, a mandatory requirement that public firms disclose their uncertain tax positions. As such disclosures are not voluntary, they are not endogenous to the firm. IRS attention substantially increased following the FIN 48 requirement (Bozanic et al., 2017). These disclosures under the FIN 48 arguably represent increasing IRS attention, which could trigger more audits and affect firm tax planning (Hoopes, Mescall, and Pittman, 2012). To save taxes, firms that experience IRS attention are hence likely to switch to the ASC regime. As IRS attention is unlikely to directly affect innovation performance, it serves as an appropriate exogenous variable to tease out the causal effect. We include firm size and sales growth because firms with stronger sales growth tend to face more difficulty in earning R\&D tax credits under the OBRA computation, and firms that experience greater sales growth tend to increase in size. We include cash effective tax rates because firms with higher taxes or more variable taxes would seek a stable way to reduce their tax burden and are more likely to choose the ASC method to reduce their tax burden. We include leverage because of a potential agency problem, as firms with less leverage are likely to be more poorly governed (Jensen, 1986). We include the cash ratio because the choice of tax credit method may depend on the firm's liquidity position. Finally, we control for K/L because it is a control commonly used in the innovation literature. ${ }^{11}$

In the second stage, we estimate Equation (3) by including the inverse Mills ratio as an additional control that is estimated from the first-stage probit regression. Table 3 shows the results for the first stage in Model 1 and for the second stage in Models 2 (patent citations) and 3 (patent counts). There are fewer observations because of data availability. Model 1 shows that firms with IRS attention are likely to switch to the ASC regime. Firms switching from the OBRA

\footnotetext{
11 Our results remain unchanged if we also include the KZ index (Kaplan and Zingales, 1997), E-index (Bebchuk, Cohen, and Ferrell, 2009), Herfindahl-Hirschman index, and state R\&D tax credit rate according to the state in which a firm is headquartered (Wilson, 2009).
} 
to the ASC regime also tend to be large and have low cash holdings, low leverage, low K/L, and high and volatile cash effective tax rates. Models 2 and 3 show that the coefficients on the interaction variable, Dummy for switching firms $\times$ Dummy for post ASC, are -0.2375 and -0.2038 , both statistically significant at the $1 \%$ level. Consistent with the findings in Table 2 , ASC users experience poorer innovation performance after enactment of the Alternative Simplified Credit than OBRA users. Thus, our results remain unchanged after accounting for a potential self-selection bias. The inverse Mills ratios are statistically insignificant in Model 2 but significant in Model 3, indicating the importance of controlling for self-selection in determining patent counts.

\section{Insert Table 3 around here}

\subsection{Sample of $R \& D$ tax credit users from $10-K$ reports}

We also estimate Equation (3) using a sample limited to the firms that indicate in their $10-$ Ks they are R\&D tax credit users. The sample size is substantially reduced. Table 4 shows that the coefficients on the interaction variable, Dummy for switching firms $\times$ Dummy for post ASC, are -0.2536 and -0.2180 for Citations and Number of patents, respectively. Both coefficients are statistically significant at the $1 \%$ level. Thus, the results are still robust in a reduced sample: Innovation performance is poorer for the ASC users than for the OBRA users following enactment of the Alternative Simplified Credit.

\section{Insert Table 4 around here}

Firms that disclose they are R\&D tax credit users in $10-\mathrm{Ks}$, however, do not indicate which regime they adopt. To address this concern, we compare their R\&D tax credits reported in $10-\mathrm{Ks}$ with our estimated R\&D tax credits. We identify a firm as an ASC user if its reported R\&D tax 
credits fall within the range between $\pm 20 \%$ of the estimated R\&D tax credits of the ASC regime and outside the range between $\pm 20 \%$ of the estimated R\&D tax credits of the OBRA regime. ${ }^{12} \mathrm{~A}$ firm is quite likely to be an ASC user if its reported R\&D tax credits are close to those obtained from the ASC formula and far away from those obtained from the OBRA formula. A similar approach is used to define an OBRA user. Internet Appendix Table A2 shows that our conclusion remains unchanged.

\subsection{Robustness checks}

We perform two robustness tests. First, the ASC statutory credit rate increased from $12 \%$ in 2007 to $14 \%$ for tax years since 2009 . We redefine the ASC user as a firm that used the OBRA method before 2009 but switched to the ASC method in 2009 or 2010 and the OBRA user as a firm that kept using OBRA throughout the sample period. Again, Dummy for switching firms is equal to one for an ASC user and zero for an OBRA user. Dummy for post ASC is redefined to be equal to one for the years after 2008, and zero otherwise. Internet Appendix Table A3 shows that our conclusion remains unchanged. The coefficients on the interaction variable, Dummy for switching firms $\times$ Dummy for post ASC, are -0.2962 for the citation regression and -0.2483 for the patent count regression, both statistically significant at the $1 \%$ level.

Second, to select control firms (OBRA users) with similar characteristics as the treatment firms (ASC users), we use a propensity score matched (PSM) sample. For each year from 2007 through 2010, we perform a probit regression where the dependent variable is equal to one for the ASC users and zero for the OBRA users, and the independent variables include $\log ($ Size $)$, Cash-to-assets ratio, Leverage, PPE-to-assets ratio, and Sales growth. The propensity score is calculated using the estimated coefficients and realizations of the corresponding independent

12 The results are similar if we use $\pm 10 \%$ or $\pm 15 \%$. 
variables for each firm. Each ASC user is then matched to an OBRA user with the closest propensity score. We also use an alternative matching approach by first forming a matched group of OBRA users within a 0.001 caliper of the ASC user's propensity score and then taking the average of the matched group for each ASC user. Internet Appendix Table A4 shows that the coefficients on Dummy for switching firms $\times$ Dummy for post ASC for patent citations and counts are significantly negative at the $5 \%$ level or better, indicating that our results are robust to the PSM sample.

\section{Conditional tests}

We perform two conditional tests to examine when the effect of the Alternative Simplified Credit on firm innovation performance might strengthen. We investigate the roles of corporate governance and innovation diversification in determining the relation between $R \& D$ tax credits and patent counts and citations.

\subsection{Corporate governance}

Firms with poorer governance are likely to suffer serious agency problems. Hoechle et al. (2012) suggest that corporate governance explains a large portion of internal capital market efficiency. ASC users that are poorly governed would tend to experience greater inefficiency in internal capital markets arising from the new R\&D tax credit regime. The Alternative Simplified Credit is predicted to have a less favorable effect on innovation performance for firms with poorer corporate governance.

We measure corporate governance using the E-index of Bebchuk, Cohen, and Ferrell (2009), which is the sum of six binary variables denoting whether a firm has poison pills, classified boards, golden parachutes, supermajority requirements, limits to amend corporate bylaws, and limits to amend corporate charters. We focus on this index as Bebchuk, Cohen, and Ferrell (2009) 
show that their index has a stronger association with firm value than the G-Index of Gompers, Ishii, and Metrick (2003). Firms with a higher E-index are viewed as having weaker shareholder rights, as it is more difficult and more costly for shareholders to remove managers. We obtain data on the E-index from RiskMetrics.

We also construct a residual governance index (RGI), in spirit similar to Jenter and Lewellen (2015), using six governance characteristics: stock ownership by the CEO, by blockholders, and by directors; board size; board independence; and an indicator for CEOs who are also the board chair. Data on board- and CEO-related information and block ownership come from GMI Ratings and BoardEx. We regress each of these governance variables on firm and CEO characteristics, including logarithm of market value of equity, book-to-market ratio, firm age, one-year past return, return on assets, leverage, PPE/book assets, sales growth, CEO tenure, CEO age, and Fama-French 48 industry and year fixed effects. We then sort each regression residual into terciles, with higher values indicating better governance, and cumulate the tercile ranks (0-2). In contrast to the E-index, firms with a higher value of RGI indicate better governance. $^{13}$

Panel A of Table 5 shows the regression results of innovation performance for the subsamples of high and low E-index firms, where high and low E-index firms are classified every year by the median of the whole U.S. listed firms with data available on the E-index. Innovation performance is measured by Citations in Models 1 and 2 and by Number of patents in Models 3 and 4. In both Models 1 and 3, the coefficients on the interaction variable, Dummy for switching firms $\times$ Dummy for post ASC, are statistically insignificant at the conventional level

\footnotetext{
13 The values are higher for firms with higher stock ownership of the CEO, blockholders, or directors, a more independent board, a smaller board size, and CEO-board chair separation. The results are unchanged if we include institutional ownership and board co-option as additional governance characteristics in constructing the residual governance index, where co-option is measured as the proportion of outside directors appointed after the incumbent CEO assumes office (Coles, Daniel, and Naveen, 2014).
} 
for firms with low E-index. However, in Models 2 and 4 the coefficients on the interaction variable for firms with high E-index are negative and statistically significant at the $5 \%$ level or better. The Wald test indicates that the differences in the coefficients on the interaction variable between high and low E-index firms are statistically significant at the $1 \%$ level for both measures of innovation performance. Thus, consistent with the prediction, the Alternative Simplified Credit has a more negative effect on innovation performance for firms with poorer corporate governance. Panel B shows that the conclusion remains unchanged when firms are classified by the residual governance index. ${ }^{14}$

\section{$\underline{\text { Insert Table } 5 \text { around here }}$}

\subsection{Innovation diversification}

The innovation diversity literature suggests that innovation-diversified firms allocate resources into divisions inefficiently and tend to suffer agency problems. For example, Holmstrom (1989) indicates that innovation activities may mix poorly with relatively routine activities in an organization. Henderson and Cockburn (1996) and Sampson (2007) also suggest that firms with greater innovation diversity are poorer in innovation performance than firms with less innovation diversity. When research teams are very dissimilar at innovative firms, the costs of innovation diversity dominate the benefits of technological diversity achieved through knowledge spillovers from team to team. Barnes, Lynham, Kalberg and Leung (2016) show that individuals tend to share information primarily with others most similar to themselves and this behavior impedes the diffusion of knowledge and working efficiency, consistent with the argument of Chen, Yang, and Lin (2013), who find a negative relation between technological

\footnotetext{
${ }^{14} \mathrm{We}$ also consider an alternative corporate governance indicator: financial experts in the audit committee. Our results show that the coefficients on the interaction variable, Dummy for switching firms $\times$ Dummy for post ASC, are stronger for those without financial experts in the audit committee. This once again supports our agency problem explanation.
} 
diversification and firm performance. ${ }^{15}$ Thus, firms with greater innovation diversity will be less efficient in allocating to different innovation teams the extra resources that come from the additional free cash flows of $\mathrm{R} \& \mathrm{D}$ tax credits. Their innovation performance is accordingly likely to suffer. We expect the Alternative Simplified Credit to have a more negative effect on innovation performance for firms engaged in diversified innovation activities.

We measure the diversity of innovation following Lerner, Sorensen, and Strömberg (2011). Let $S_{i}=\left(S_{i, 1}, \ldots, S_{i, k}\right)$ be a vector of innovation activity in $k$ technology areas for firm $i$, where $k$ indicates a technology classification of six technology classifications in Hall, Jaffe, and Trajtenberg $(2001,2005) .{ }^{16}$ Innovation activity is measured by the number of patents that a firm applies for. The diversification of innovation is:

$$
H_{H}^{i n n o v}=\left(S_{i k} / \sum_{k} S_{i k}\right)^{2}
$$

Firms with a high (low) value of $H H I^{i n n o v}$ have a low (high) level of innovation diversity.

Table 6 presents the regression results of innovation performance for the subsamples of firms with high and low innovation diversity classified every year by the median of all U.S. listed firms that have data available on $H H I^{\text {innov }} .{ }^{17}$ We measure innovation performance by Citations in Models 1 and 2 and Number of patents in Models 3 and 4. In Models 1 and 3, the coefficients on the interaction variable, Dummy for switching firms $\times$ Dummy for post ASC, are negative and statistically significant at the $1 \%$ level for firms with high innovation diversity (i.e., low $H H I^{i n n o v}$ firms). In Models 2 and 4, the coefficients on the interaction variable are not

\footnotetext{
15 This evidence is consistent with the product diversification literature (e.g., Stein, 1997; Rajan, Servaes, and Zingales, 2000; Wulf, 2009). See, for example, Martin and Sayrak (2003) for a review.

16 The six technological categories include chemical, computers and communication, drugs and medical, electrical and electronics, mechanical, and other.

17 Our results are similar if we divide our sample into innovation-diversified firms (i.e., $H H I^{\text {innov }}<1$ ) and innovation-focused firms (i.e., $H H I^{\text {innov }}=1$ ).
} 
statistically significant at the conventional level for firms with more focused innovation activity (i.e., high $H H I^{i n n o v}$ firms). The Wald test indicates that the differences in the two coefficients on the interaction variable between high and low $H H I^{\text {innov }}$ firms are statistically significant at the $1 \%$ level for both measures of innovation performance. Thus, the Alternative Simplified Credit has stronger negative effects on innovation performance when firms face a higher level of innovation diversification.

\section{Insert Table 6 around here}

\section{Additional analyses}

\subsection{Alternative measures of innovation performance}

We have shown that ASC users experience poorer innovation performance after enactment of the Alternative Simplified Credit than OBRA users, supporting a negative view of the effect of R\&D tax credits. We examine now whether our results hold using six other measures of innovation performance suggested by prior research: Generality, Originality, Relative citations, Self-citations, Non-self-citations, and Aggregate citations. Generality is defined as the sum of squared ratios of forward-citations divided by the number of total forward citations in the same International Patent Classification (IPC) code. A patent with greater generality is more influential in various technology areas. Originality is measured using a similar formula but replacing forward-citations by backward-references. Patent originality captures the diversification of technology knowledge background, so a patent has more originality if it does not rely on the knowledge pool of a specific area. Relative citations are citations per patent divided by the median of citations per patent in the same IPC classification. We further classify patent citations into Self-citations and Non-self-citations. Self-citations are the number of 
self-citations divided by the number of patents that a firm applied for, where self-citations are identified as citing patents assigned by their inventors to the sample firms as the originating patents. Since higher self-citations imply less knowledge outgoing spillover because the patents are owned by the same company, self-citations are usually more favorable to the firm (Hall, Jaffe, and Trajtenberg, 2001). Non-self-citations are defined as the number of non-self-citations divided by the number of patents that a firm applied for. Aggregate citations are computed as the aggregate citations of patents for a firm, a measure without scaling patent counts.

Table 7 presents our regression results using these alternative measures of innovation performance from 2003 through 2014. The coefficients on Dummy for switching firms $\times$ Dummy for post ASC remain negative and statistically significant at the $5 \%$ level or better for all six models. Thus, our findings are robust to alternative measures of innovation performance.

\section{Insert Table 7 around here}

\subsection{Firm performance and value}

If enactment of the Alternative Simplified Credit weakens innovation outputs, the performance and value of the firm using the new R\&D tax credit regime will likely suffer. To examine this issue, we use the three-year average of firm operating performance over $t+1$ and $t$ +3 and firm value in $t+1$ as the dependent variables. We measure operating performance by earnings before extraordinary items plus pre-tax R\&D expenses divided by book assets. We add back pre-tax R\&D expenses because R\&D reduces earnings (Eberhart, Maxwell, and Siddique, 2004). We measure firm value by Tobin's $Q$ based on the valuation of physical capital in Peters and Taylor (2017), which is equal to the market value of equity plus the book value of debt and the book value of preferred equity minus inventories and deferred taxes, divided by the book value of capital (proxied by property, plant, and equipment). 
Model 1 of Table 8 presents the results for the regression of operating performance by including common control variables from prior research (e.g., Fama and French, 2000; Huson, Malatesta, and Parrino, 2004; Chen and Wang, 2012; Hirshleifer, Hsu, and Li, 2013). The coefficient on the interaction variable, Dummy for switching firms $\times$ Dummy for post ASC, is -0.1511 , which is statistically significant at the $1 \%$ level. The evidence indicates that ASC users are less profitable than OBRA users after enactment of the Alternative Simplified Credit, consistent with our results for innovation performance. In Model 2, we report regressions of firm value by including controls suggested in the literature (e.g., Szewczyk, Tsetsekos, and Zantout, 1996; Palia and Lichtenberg, 1999; Demsetz and Villalonga, 2000; Hirshleifer, Hsu, and Li, 2013). There are fewer observations because of data availability. We continue to find a significantly negative coefficient on the interaction term. That is, R\&D tax credits gained through the Alternative Simplified Credit are associated with lower firm valuations. ${ }^{18}$

\section{$\underline{\text { Insert Table } 8 \text { around here }}$}

\subsection{Young firms}

Under the OBRA method, sales growth is a key factor in computing $R \& D$ tax credits. Some firms such as start-ups or young firms are less likely to qualify for R\&D tax credits because they are experiencing strong sales growth. The U.S. tax code may in fact facilitate their innovation activities through use of the ASC method. This suggests that our results using difference-in-differences analysis that investigates changes in innovation performance between ASC and OBRA users may be biased, due to the likely exclusion of young firms.

To test this conjecture, we compare innovation performance between two groups of new

\footnotetext{
18 The results in Table 8 hold when the dependent and control variables are winsorized at the 1st and 99th percentiles.
} 
firms that went public after 2002. Group A consists of start-ups that never gained R\&D tax credits during our sample period, and Group B consists of start-ups that did not seek R\&D tax credits before 2007 but gained R\&D tax credits through the ASC method. We define Dummy for ASC start-ups to be equal to one if a start-up belongs to Group B, and zero if it belongs to Group A. Table 9 presents regression results of Citations and Number of patents for the sample of start-ups that includes Groups A and B. Both coefficients on the interaction variable, Dummy for ASC start-ups $\times$ Dummy for post ASC, are positive but statistically insignificant at the conventional level. The results indicate that start-ups using the ASC method do not have better or poorer innovation performance than other start-ups. This suggests that our conclusion is unlikely to be driven by the exclusion of young firms.

\section{Insert Table 9 around here}

\subsection{Q-theory}

We examine whether our findings can be also explained by $q$-theory, which argues that firms choose investment projects according to net present values and decide their optimal investment when marginal revenue equals the marginal cost of capital (e.g., Liu, Whited, and Zhang, 2009; Li and Zhang, 2010; Wu, Zhang, and Zhang, 2010). For $q$-theory to explain our finding that ASC users have poorer innovation performance than OBRA users in the post-ASC period, the firm production function must exhibit decreasing or constant returns to scale. Thus, $q$-theory predicts the Alternative Simplified Credit would have a stronger negative effect on innovation performance for ASC users with decreasing or constant returns to scale than for those with increasing returns to scale.

We consider a Cobb-Douglas production function with inputs of labor, capital, and R\&D and with outputs of firm revenues. The production function is estimated for each firm using its 
time-series data. The returns to scale are equal to the sum of output elasticities of labor, capital, and R\&D from the estimated production function. Table 10 shows the regression results of innovation performance classified by returns to scale, where sample firms are divided into a subsample with increasing returns to scale and a subsample with decreasing or constant returns to scale. Models 1 and 2 show that, when innovation performance is measured by Citations, the coefficients on the interaction variable, Dummy for switching firms $\times$ Dummy for post ASC, are both significantly negative at the $1 \%$ level for the two subsamples. The Wald test indicates no significant difference between these two coefficients. Similar findings are obtained when we measure innovation performance by Number of Patents. Thus, our results are unlikely to be explained by $q$-theory.

\section{Insert Table 10 around here}

\subsection{R\&D spillover}

The enactment of the Alternative Simplified Credit may stimulate technology expansion, which presumably helps improve social benefits associated with research activities. A firm's R\&D investment usually has strong positive externalities in that it produces benefits that accrue to parties other than the firm making the investment (Jaffe, 1986; Cassiman and Veugelers, 2002). Thus, it is possible that, while an ASC user may experience poorer innovation performance, other firms may benefit from R\&D spillover effects, and hence social benefits increase.

To investigate this issue, we perform regressions of $R \& D$ spillover effects using the spillover measure of Jaffe (1986), Bloom, Schankerman, and Van Reenen (2013), and Qiu and Wan (2015). To estimate the R\&D spillover effect, we define technological proximity as an uncentered correlation coefficient of innovation activities of two firms $i$ and $j$ : 


$$
\frac{S_{i} S_{j}^{\prime}}{\sqrt{S_{i} S_{i}^{\prime}} \sqrt{S_{j} S_{j}^{\prime}}},
$$

where $S_{i}=\left(S_{i, 1}, \ldots, S_{i, k}\right)$ is a vector of innovation activity in technology classification $k$ for firm $i$. We use six technology classifications as in Hall, Jaffe, and Trajtenberg (2001, 2005), and measure innovation activity by the number of patents that a firm has applied for at the U.S. Patent and Trademark Office. The R\&D spillover effect is estimated as:

$$
\sum_{j \neq i} w_{i j} C R D_{j t},
$$

where $w_{i j}$ is proximity between firms $i$ and $j$, and firm $j$ is in the same three-digit SIC industry as firm $i$; $C R D$ is firm R\&D capital (Chan, Lakonishok, and Sougiannis, 2001). ${ }^{19}$ Because we obtain missing $w_{i j}$ when firm $j$ generates zero patents in year $t$, we either replace missing values of $w_{i j}$ with zero or simply drop the observation in our analysis.

We perform regression analysis of the R\&D spillover effect using the same explanatory variables as those in Equation (3). Table 11 presents the results, where Model 1 replaces the missing values of $w_{i j}$ with zero and Model 2 drops the observation with missing $w_{i j}$. Model 1 shows that the coefficient on the interaction variable, Dummy for switching firms $\times$ Dummy for post $A S C$, is negative and statistically significant at the $10 \%$ level. Model 2 shows that the coefficient on the interaction variable is statistically insignificant at the conventional level. Thus, we find no evidence that the ASC method contributes to greater R\&D spillover than the OBRA method in the post-ASC period, suggesting that the ASC method does not produce greater technology dispersion.

\section{Insert Table 11 around here}

19 We also estimate the R\&D spillover effect using the methodology of Chen et al. (2013) and obtain similar results. 


\subsection{Effect of the 1981 OBRA on innovation performance}

We investigate how the Omnibus Budget Reconciliation Act first enacted in 1981 affects firm innovation performance. This issue is important, as the OBRA regime may have already had a negative effect on innovation performance. If this is true, our findings for the ASC are just reconfirmation of the evidence under a different $R \& D$ tax credit regime. We collect a sample of U.S. firms between 1974 and 2006, and perform a difference-in-differences analysis. We examine whether the change in innovation performance is different for OBRA users and other firms without R\&D tax credits following the 1981 Omnibus Budget Reconciliation Act.

In Table 12, we report the regression results of Citations (Model 1) and Number of Patents (Model 2) over the period from 1974 through 2006. Dummy for OBRA firms is equal to one if a firm did not use R\&D tax credits before 1981 but applied for R\&D tax credits through the OBRA in any year from 1981 through 2006, and zero if a firm did not use any R\&D tax credits from 1974 through 2006. Dummy for post OBRA is equal to one for the years after 1980, and zero otherwise. Control variables are the same as those in Equation (3). Models 1 and 2 show that the coefficients on the interaction variable, Dummy for OBRA firms $\times$ Dummy for post $O B R A$, are 0.0860 and 0.0655 , both statistically significant at the $5 \%$ level. The results indicate that the OBRA users significantly increased in both citations per patent and number of patents over other firms following the 1981 OBRA enactment. Thus, in contrast to the poorer firm innovation performance associated with enactment of the Alternative Simplified Credit, the Omnibus Budget Reconciliation Act improved the performance of innovation.

\section{$\underline{\text { Insert Table } 12 \text { around here }}$}

\subsection{Placebo test}

We conduct a placebo test to examine whether our findings are driven merely by chance, an 
issue in part related to the data snooping bias. We replace each ASC user with another firm randomly selected from among OBRA users (i.e., pseudo-ASC users). We re-run the regression for Equation (3) by replacing Dummy for switching firms by Dummy for switching placebos, which is equal to one for a pseudo-ASC user, and zero otherwise. We record the coefficient on the interaction variable, Dummy for switching placebos $\times$ Dummy for post ASC. We repeat this procedure 1,000 times and hence obtain 1,000 estimated coefficients on the interaction variable. As the pseudo-ASC users are randomly assigned from among OBRA users, we expect the Alternative Simplified Credit to have an insignificant impact on their innovation performance.

Figure 1 shows the distribution of the estimated coefficients on Dummy for switching placebos $\times$ Dummy for post ASC for innovation performance measured by Citations in Panel A and by Number of patents in Panel B. In Panel A, the mean and median coefficients on the interaction variable are -0.0182 and -0.0179 , which are statistically insignificantly different from zero at the conventional level. The magnitudes of these coefficients are also much smaller than the magnitude of the coefficient on Dummy for switching firms $\times$ Dummy for post ASC in Model 1 of Table 2. We obtain similar results in Panel B. The mean and median coefficients on the interaction variable are -0.0277 and -0.0274 , again statistically insignificantly different from zero and smaller in magnitude than the coefficient on Dummy for switching firms $\times$ Dummy for post ASC in Model 2 of Table 2. Thus, there is no evidence for the significant impact of the Alternative Simplified Credit on the innovation performance of the pseudo-ASC users, suggesting that our results are unlikely driven by pure luck.

\section{Insert Figure 1 around here}

\subsection{Another self-selection issue}

We have controlled for the potential bias arising from self-selection between the OBRA and 
ASC methods in Section 4.2 (Table 3). Another self-selection bias, however, could be present, as the decision of whether to use R\&D tax credits at all is also voluntary. To address this issue, we again perform Heckman's two-stage regression analysis. In the first stage, we use all the firms covered by Compustat and CRSP and perform a probit regression of Dummy for $R \& D$ tax credit users, which is equal to one if a firm uses the OBRA method before 2007 and the OBRA or ASC method over the period from 2007 through 2010, and zero otherwise. The explanatory variables are the same as those in Table 3. In the second stage, we perform regressions of innovation performance for the sample of OBRA and ASC users by additionally controlling for the inverse Mills ratio estimated from the first-stage probit regression. Internet Appendix Table A5 shows that the coefficients on the interaction variable, Dummy for switching firms $\times$ Dummy for post $A S C$, are still negative and statistically significant at the $1 \%$ level for both measures of innovation performance. Thus, our results remain robust to this potential self-selection bias.

\section{Conclusion}

The U.S. government provides direct tax incentives through R\&D tax credits with an aim to encourage corporate innovation. Researchers have focused on innovation inputs and documented that such a tax policy encourages corporate R\&D expenditures. Our work contributes to the firm innovation literature by examining how $R \& D$ tax credits affect the performance of firm innovation outputs. We investigate this issue taking advantage of a new U.S. federal tax policy effective in 2007, the Alternative Simplified Credit (ASC), as a quasi-experiment. Under this regime, firms can choose between two methods for determining $R \& D$ tax credits, the original Omnibus Budget Reconciliation Act (OBRA) method or the new ASC method, but switching to the ASC method is an irreversible choice. 
We use a difference-in-differences approach to investigate the change in innovation performance between firms switching from OBRA to ASC (i.e., ASC users) and firms staying with OBRA (i.e., OBRA users). We report that ASC users had a significant reduction in citations per patent and number of patents relative to OBRA users following enactment of the Alternative Simplified Credit. The results indicate that the new federal tax policy in fact resulted in a deterioration in firm innovation output performance. The evidence favors a dark-side rather than bright-side view of the effects of R\&D tax credits under the ASC regime. The findings remain robust when we control for potential self-selection bias, use a propensity score matched sample, or use alternative measures of innovation performance. Thus, our research calls into question whether the new tax incentives enacted since 2007 to stimulate R\&D investments have a positive economic impact for firms.

We also examine the roles of corporate governance and innovation diversity in explaining the negative effect of the Alternative Simplified Credit on firm innovation performance. We show that this negative effect is more profound for firms with poorer governance mechanisms. The evidence supports the argument that inefficiency in internal capital markets resulting from the ASC method is likely greater for ASC users that are less well governed. We also show a stronger negative effect of ASC on innovation performance for firms that face a higher level of innovation diversification. That is, firms with more diversified innovation activities are likely less efficient in allocating the extra resources that arise from additional free cash flows of ASC tax benefits to different innovation teams. Hence, they suffer a greater deterioration in innovation performance.

A number of additional tests corroborate these findings. We examine firm performance and value, and show that ASC users experience poorer profitability and lower valuations than OBRA 
users following the ASC enactment. We rule out the possibility that our conclusion is driven by the exclusion of young firms, as we find that start-ups using the ASC regime do not have better or worse innovation performance than other start-ups. Our findings are also not explained by $q$-theory, which predicts that the ASC method will have a less favorable impact on innovation performance for firms with decreasing or constant returns to scale than firms with increasing returns to scale. We show no evidence of significant difference in the ASC effect on innovation performance between these two groups of firms. We further find that the ASC method does not lead to greater R\&D spillover than the OBRA method, suggesting that the ASC method does not produce greater technology dispersion to benefit other firms' innovation. Finally, we show that, in contrary to our primary finding that ASC users experience a deterioration in innovation performance, the Omnibus Budget Reconciliation Act improves firm innovation performance. Thus, our findings for ASC effects are not just reconfirmation of the evidence under a different R\&D tax credit regime. 


\section{References}

Aghion, P., Reenen, J.V., Zingales, L., 2013. Innovation and institutional ownership. American Economic Review 103: 277-304.

Atanassov, J., Liu, X., 2019. Can Corporate Income Tax Cuts Stimulate Innovation? Journal of Financial and Quantitative Analysis, forthcoming.

Barnes, M., Lynham, J., Kalberg, K., Leung, P.S., 2016. Social networks and environmental outcomes. Proceedings of the National Academy of Sciences 113: 6466-6471.

Bebchuk, L., Cohen, A., Ferrell, A., 2009. What matters in corporate governance? Review of Financial Studies 22: 783-827.

Becker-Blease, J.R., 2011. Governance and innovation. Journal of Corporate Finance 17: 947-958.

Belenzon, S., Berkovitz, T., 2010. Innovation in business groups. Management Science 56: $519-535$.

Bena, J., Li, K., 2014. Corporate innovations and mergers and acquisitions. Journal of Finance 69: $1923-1960$.

Bloom, N., Griffith, R., Reenen, J.V., 2002. Do R\&D tax credits work? Evidence from a panel of countries 1979-1997. Journal of Public Economics 85: 1-31.

Bloom, N., Schankerman, M., Reenen, J.V., 2013. Identifying technology spillovers and product market rivalry. Econometrica 81: 1347-1393.

Bozanic, Z., Hoopes, J.L., Thornock, J.R., Williams, B.M., 2017. IRS attention. Journal of Accounting Research 55: 79-114.

Bradley, D., Kim, I., Tian, X., 2016. Do unions affect innovation? Management Science 63: 2251-2271. 
Cassiman, B., Veugelers, R., 2002. R\&D cooperation and spillovers: some empirical evidence from Belgium. American Economic Review 92: 1169-1184.

Chan, L.K.C., Lakonishok, J., Sougiannis, T., 2001. The stock market valuation of research and development expenditures. Journal of Finance 56: 2431-2456.

Chang, X., Fu, K., Low, A., Zhang, W., 2015. Non-executive employee stock options and corporate innovation. Journal of Financial Economics 115: 168-188.

Chen, S., Chen, Y., Liang, W., Wang, Y., 2013. R\&D spillover effects and firm performance following R\&D increases. Journal of Financial and Quantitative Analysis 48: 1607-1634.

Chen, S., Wang, Y., 2012. Financial constraints and share repurchases. Journal of Financial Economics 105: 311-331.

Chen, Y., Yang, D., Lin, F., 2013. Does technological diversification matter to firm performance? The moderating role of organizational slack. Journal of Business Research 66: 1970-1975.

Coles, J.L., Daniel, N.D., Naveen, L., 2014. Co-opted boards. Review of Financial Studies 27: $1751-1796$.

Desai, M., Dharmapala, D., 2006. Corporate tax avoidance and high-powered incentives. Journal of Financial Economics 79: 145-179.

Demsetz, H., Villalonga, B., 2000. Ownership structure and corporate performance. Journal of Corporate Finance 7: 209-233.

Eberhart, A.C., Maxwell, W.F., Siddique, A.R., 2004. An examination of long-term abnormal stock returns and operating performance following R\&D increases. Journal of Finance 59: $623-650$.

Ederer, F., Manso, G., 2013. Is pay for performance detrimental to innovation?. Management Science 59: 1496-1513. 
Fama, E.F., French, K.R., 2000. Forecasting profitability and earnings. Journal of Business 73: $161-175$.

Fang, V.W., Tian, X., Tice, S., 2014. Does stock liquidity enhance or impede firm innovation? Journal of Finance 69: 2085-2125.

Finley, A.R., Lusch, S.J., Cook, K.A., 2015. The effectiveness of the R\&D tax credit: evidence from the Alternative Simplified Credit. Journal of the American Taxation Association 37: $157-181$.

Gompers, P., Ishii, J., Metrick, A., 2003. Corporate governance and equity prices. Quarterly Journal of Economics 118: 107-155.

Grigsby, M., Westmoreland, J.W., 2001. The research tax credit: a temporary and incremental dinosaur. Tax Notes 93: 1627-1640.

Hall, B.H., Jaffe, A.B., Trajtenberg, M., 2001. The NBER patent citation data file: lessons, insights and methodological tools. NBER Working paper 8498.

Hall, B.H., Jaffe, A.B., Trajtenberg, M., 2005. Market value and patent citations. RAND Journal of Economics 36: 16-38.

Hall, B.H., and Reenen, J.V., 2000. How effective are fiscal incentives for R\&D? A review of the evidence. Research Policy 29: 449-469.

Hall, R.E., Jorgenson, D.W., 1967. Tax policy and investment behavior. American Economic Review 57: 391-414.

Hanlon, M., 2005. The persistence and pricing of earnings, accruals, and cash flows when firms have large book-tax differences. The Accounting Review 80: 137-166.

Hanlon, M., Heitzman, S., 2010. A review of tax research. Journal of Accounting and Economics 50: 127-178. 
He, J.J., Tian, X., 2013. The dark side of analyst coverage: the case of innovation. Journal of Financial Economics 109: 856-878.

Heckman, J.J., 1979. Sample selection bias as a specification error. Econometrica 47: 153-161.

Henderson, R., Cockburn, I., 1996. Scale, scope, and spillovers: the determinants of research productivity in drug discovery. RAND Journal of Economics 27: 32-59.

Hirshleifer, D., Hsu, P., Li, D., 2013. Innovative efficiency and stock returns. Journal of Financial Economics 107: 632-654.

Hoechle, D., Schmid, M., Walter, I., Yermack, D., 2012. How much of the diversification discount can be explained by poor corporate governance? Journal of Financial Economics 103: 41-60.

Holmstrom, B., 1989. Agency costs and innovation. Journal of Economic Behavior and Organization 12: 305-327.

Hoopes, J.L., Mescall, D., Pittman, J.A., 2012. Do IRS audits deter corporate tax avoidance? The Accounting Review 87: 1603-1639.

Hsu, P., 2009. Technological innovations and aggregate risk premiums. Journal of Financial Economics 94: 264-279.

Hsu, P., Tian, X., Xu, Y., 2014. Financial development and innovation: cross-country evidence. Journal of Financial Economics 112: 116-135.

Huson, M.R., Malatesta, P.H., Parrino, R., 2004. Managerial succession and firm performance. Journal of Financial Economics 74: 237-275.

Jaffe, A.B., 1986. Technological opportunity and spillovers of R\&D: evidence from firms' patents, profits, and market value. American Economic Review 76: 984-1001. 
Jaffe, A.B., 2000. The U.S. patent system in transition: policy innovation and the innovation process. Research Policy 29: 531-557.

Jensen, M.C., 1986. Agency costs of free cash flow, corporate finance, and takeovers. American Economic Review 76: 323-329.

Jensen, M.C., 1993. The modern industrial revolution, exit, and the failure of internal control systems. Journal of Finance 48: 831-880.

Jenter, D., Lewellen, K., 2015. CEO preferences and acquisitions. Journal of Finance 70: 2813-2852.

Kaplan, S.N., Zingales, L., 1997. Do investment-cash flow sensitivities provide useful measures of financing constraints? Quarterly Journal of Economics 112: 169-215.

Lang, L.H.P., Stulz, R.M., Walkling, R.A., 1991. A test of the free cash flow hypothesis: the case of bidder returns. Journal of Financial Economics 29: 315-335.

Laplante, S.K., Skaife, L.A., Swenson, L.A., Wangerin, D.D., 2019. Limits of tax regulation: Evidence from strategic R\&D classification and the R\&D tax credit. Journal of Accounting and Public Policy 38: 89-105.

Lehn, K., Poulsen, A., 1989. Free cash flow and stockholder gains in going private transactions. Journal of Finance 44: 771-787.

Lerner, J., Sorensen, M., Strömberg, P., 2011. Private equity and long-run investment: the case of innovation. Journal of Finance 66: 445-477.

Lev, B., Nissim, D, 2004. Taxable income, future earnings, and equity values. The Accounting Review 79: 1039-1074.

Li, D., Zhang, L., 2010. Does $q$-theory with investment frictions explain anomalies in the cross-section of returns? Journal of Financial Economics 98: 297-314. 
Liu, L.X., Whited, T.M., Zhang, L., 2009. Investment-based expected stock returns. Journal of Political Economy 117: 1105-1139.

Mansfield, E., 1986. The R\&D tax credit and other technology policy issues. American Economic Review 76: 190-194.

Martin, J.D., Sayrak, A., 2003. Corporate diversification and shareholder value: a survey of recent literature. Journal of Corporate Finance 9: 37-57.

Mukherjee, A., Singh, M., Žaldokas, A., 2017. Do corporate taxes hinder innovation? Journal of Financial Economics 124: 195-221.

Palia, D., Lichtenberg, F., 1999. Managerial ownership and firm performance: a re-examination using productivity measurement. Journal of Corporate Finance 5: 323-339.

Peters, R.H., Taylor, L.A., 2017. Intangible capital and the investment- $q$ relation. Journal of Financial Economics 123: 251-272.

Png, I., 2017. Law and innovation: evidence from state trade secrets laws. Review of Economics and Statistics 99: 167-179.

Qiu, J., Wan, C., 2015. Technology spillovers and corporate cash holdings. Journal of Financial Economics 115: 558-573.

Rajan, R., Servaes, H., Zingales, L., 2000. The cost of diversity: the diversification discount and inefficient investment. Journal of Finance 55: 35-80.

Rao, N., 2016. Do tax credits stimulate R\&D spending? The effect of the R\&D tax credit in its first decade. Journal of Public Economics 140: 1-12.

Sampson, R.C., 2007. R\&D alliances and firm performance: the impact of technological diversity and alliance organization on innovation. Academy of Management Journal 50: 364-386. 
Seru, A., 2014. Firm boundaries matter: evidence from conglomerates and R\&D activity. Journal of Financial Economics 111: 381-405.

Stein, J.C., 1997. Internal capital markets and the competition for corporate resources. Journal of Finance 52: 111-133.

Summers, L.H., Bosworth, B.P., Tobin, J., White, P.M., 1981. Taxation and corporate investment: a $q$-theory approach. Brookings Papers on Economic Activity 12: 67-140.

Szewczyk, S.H., Tsetsekos, G.P., Zantout, Z., 1996. The valuation of corporate R\&D expenditures: evidence from investment opportunities and free cash flow. Financial Management 25: 105-110.

Wilson, D.J., 2009. Beggar thy neighbor? The in-state, out-of-state, and aggregate effects of R\&D tax credits. Review of Economics and Statistics 91: 431-436.

Wu, J., Zhang, L., Zhang, X.F., 2010. The $q$-theory approach to understanding the accrual anomaly. Journal of Accounting Research 48: 177-223.

Wulf, J., 2009. Influence and inefficiency in the internal capital market. Journal of Economic Behavior and Organization 72: 305-321. 
Table 1

Descriptive statistics.

Panel A: Industry distribution

\begin{tabular}{lrrrrrr}
\hline Fama and French 48-industry classifications & All firms & \multicolumn{1}{c}{$\%$} & OBRA users & \multicolumn{1}{c}{$\%$} & ASC users & \multicolumn{1}{c}{$\%$} \\
\hline Business services (34) & 490 & 14.44 & 408 & 14.44 & 82 & 14.41 \\
Computers (35) & 215 & 6.33 & 162 & 5.73 & 53 & 9.31 \\
Electronic equipment (36) & 386 & 11.37 & 299 & 10.58 & 87 & 15.29 \\
Machinery (21) & 158 & 4.66 & 128 & 4.53 & 30 & 5.27 \\
Measuring and control equipment (37) & 131 & 3.86 & 102 & 3.61 & 29 & 5.10 \\
Medical equipment (12) & 225 & 6.63 & 190 & 6.73 & 35 & 6.15 \\
Pharmaceutical products (13) & 499 & 14.70 & 463 & 16.39 & 36 & 6.33 \\
Others & 1,290 & 38.01 & 1,073 & 37.98 & 217 & 38.14 \\
\hline
\end{tabular}

Panel B: Estimated R\&D tax credits

\begin{tabular}{|c|c|c|c|c|c|}
\hline \multirow{2}{*}{ Year } & \multicolumn{3}{|c|}{ OBRA users } & \multicolumn{2}{|c|}{ ASC users } \\
\hline & \multicolumn{2}{|c|}{$\begin{array}{l}\text { Estimated OBRA } \\
\text { Tax credits }\end{array}$} & $\begin{array}{c}\text { Estimated ASC } \\
\text { tax credits }\end{array}$ & $\begin{array}{c}\text { Estimated OBRA } \\
\text { tax credits }\end{array}$ & $\begin{array}{l}\text { Estimated ASC } \\
\text { tax credits }\end{array}$ \\
\hline 2007 & \multicolumn{2}{|c|}{6.642} & 5.868 & 12.292 & 12.894 \\
\hline 2008 & \multicolumn{2}{|c|}{7.712} & 6.610 & 10.693 & 13.119 \\
\hline 2009 & \multicolumn{2}{|c|}{6.914} & 6.277 & 6.267 & 12.401 \\
\hline 2010 & \multicolumn{2}{|c|}{7.000} & 6.532 & 8.116 & 14.772 \\
\hline Average & \multicolumn{2}{|c|}{7.052} & 6.266 & 9.450 & 13.268 \\
\hline \multicolumn{6}{|c|}{ Panel C: Firm characteristics before ASC was enacted } \\
\hline & $\mathrm{N}$ & \multicolumn{2}{|c|}{ Variable } & Mean & Median \\
\hline \multirow[t]{10}{*}{ OBRA users } & \multirow[t]{10}{*}{2,825} & \multicolumn{2}{|c|}{ Citations } & 0.614 & 0.000 \\
\hline & & \multicolumn{2}{|c|}{ Number of patents } & 0.585 & 0.000 \\
\hline & & \multicolumn{2}{|c|}{ R\&D expenditures } & 130.693 & 11.472 \\
\hline & & \multicolumn{2}{|l|}{ Size } & 3523.110 & 101.613 \\
\hline & & \multicolumn{2}{|c|}{$\mathrm{R} \& \mathrm{D}$-to-assets ratio } & 0.279 & 0.107 \\
\hline & & \multicolumn{2}{|c|}{ Cash-to-assets ratio } & 0.602 & 0.328 \\
\hline & & \multicolumn{2}{|c|}{ Leverage } & 0.148 & 0.001 \\
\hline & & \multicolumn{2}{|l|}{ ROA } & -0.226 & 0.104 \\
\hline & & \multicolumn{2}{|l|}{$\mathrm{M} / \mathrm{B}$} & 2.916 & 2.727 \\
\hline & & \multicolumn{2}{|l|}{$\mathrm{K} / \mathrm{L}$} & 0.121 & 0.075 \\
\hline \multirow[t]{10}{*}{ ASC users } & \multirow[t]{10}{*}{569} & \multicolumn{2}{|c|}{ Citations } & 0.821 & 0.000 \\
\hline & & \multicolumn{2}{|c|}{ Number of patents } & 0.895 & 0.000 \\
\hline & & \multicolumn{2}{|c|}{ R\&D expenditures } & 284.109 & 21.963 \\
\hline & & \multicolumn{2}{|c|}{ Size } & 5815.610 & 347.898 \\
\hline & & \multicolumn{2}{|c|}{ R\&D-to-assets ratio } & 0.111 & 0.081 \\
\hline & & \multicolumn{2}{|c|}{ Cash-to-assets ratio } & 0.398 & 0.242 \\
\hline & & \multirow{2}{*}{\multicolumn{2}{|c|}{$\begin{array}{l}\text { Leverage } \\
\text { ROA }\end{array}$}} & 0.241 & 0.034 \\
\hline & & & & 0.082 & 0.159 \\
\hline & & $\mathrm{M} / \mathrm{B}$ & & 3.620 & 2.596 \\
\hline & & $\mathrm{K} / \mathrm{L}$ & & 0.123 & 0.079 \\
\hline
\end{tabular}

This table presents summary statistics of U.S. public firms claiming R\&D tax credits under two different regimes. ASC users represent a subsample of firms applying for Omnibus Budget Reconciliation Act (OBRA) credits before 2007 but using the Alternative Simplified Credit (ASC) method in any year between 2007 and 2010. OBRA users represent a subsample of firms staying in the OBRA regime in both pre- and post-2007 periods. Panel A shows the sample distribution based on Fama-French 48 industry classifications (numbers in parentheses are industry codes). Panel B presents the average estimated R\&D tax credits (in millions of dollars) per year for the OBRA users and the ASC users. Panel C shows summary statistics of firm characteristics in 2006, the year before enactment of the ASC. Citations are the number of truncation-adjusted citations divided by the number of patents that a firm applied for. Number of patents is the number of patents that a firm applied for. $R \& D$ expenditures are the dollar amount of $R \& D$ expenditures (in millions). Size is book assets (in millions). $R \& D$-to-assets ratio is $\mathrm{R} \& \mathrm{D}$ expenditures divided by book assets. Cash-to-assets ratio is cash divided by book assets. Leverage is long-term debt divided by common equity. $R O A$ is earnings before extraordinary items divided by book assets. $M / B$ is the market value of common equity divided by the book value of common equity. $K / L$ is property, plant, and equipment (PPE) divided by number of employees. 
Table 2

Relation between R\&D tax credits and innovation performance.

\begin{tabular}{lcc}
\hline & $\log (1+$ Citations $)$ & $\log (1+$ Number of patents $)$ \\
\cline { 2 - 3 } Variable & Model 1 & Model 2 \\
\hline Dummy for switching firms & $0.1367^{* *}$ & $0.1657^{* * *}$ \\
Dummy for post ASC & $(2.52)$ & $(2.66)$ \\
& $-0.7660^{* * *}$ & $-0.4213^{* * *}$ \\
Dummy for switching firms & $(-21.29)$ & $(-11.53)$ \\
$\quad \times$ Dummy for post ASC & $-0.2308^{* * *}$ & $-0.2276^{* * *}$ \\
R\&D-to-assets ratio & $(-5.78)$ & $(-5.51)$ \\
& $0.1437^{* * *}$ & $0.2382^{* * *}$ \\
Log(Size) & $(5.08)$ & $(8.02)$ \\
& $0.1054^{* * *}$ & $0.1776^{* * *}$ \\
Cash-to-assets ratio & $(12.53)$ & $(12.46)$ \\
& $0.0333^{* * *}$ & $0.0296^{* * * *}$ \\
Leverage & $(3.77)$ & $(3.57)$ \\
& -0.0106 & -0.0197 \\
ROA & $(-0.84)$ & $(-1.35)$ \\
& $0.0113^{*}$ & -0.0107 \\
M/B & $(1.86)$ & $(-1.57)$ \\
& $0.0016^{* *}$ & $0.0026^{* * *}$ \\
K/L & $(2.06)$ & $(3.34)$ \\
Intercept & -0.0043 & 0.0522 \\
Industry FE & $(-0.04)$ & $(0.32)$ \\
N & -0.0953 & $-0.8331^{* * *}$ \\
Adj. $\mathrm{R}^{2}$ & $(-0.46)$ & $(-5.97)$ \\
Ths & Yes & Yes \\
& 15,092 & 15,092 \\
& 0.106 & 0.167 \\
\hline
\end{tabular}

This table presents regressions of innovation performance using a sample of U.S. public firms adopting the OBRA or ASC method. The dependent variable refers to the two measures of firm innovation performance over the period from 2003 through 2014, Citations in Model 1 and Number of patents in Model 2. Citations are the number of truncation-adjusted citations divided by the number of patents applied for by a firm. Number of patents is the number of patents applied for. Dummy for switching firms is equal to one for an ASC user and zero for an OBRA user. Dummy for post ASC is equal to one for the years after 2006, and zero otherwise. Other variables are defined in Table 1. Numbers in parentheses are $t$-statistics computed using standard errors clustered by firm. ***, **, and * denote significance at the $1 \%, 5 \%$, and $10 \%$ levels, respectively. 
Table 3

Relation between R\&D tax credits and innovation performance after controlling for selfselection bias.

\begin{tabular}{|c|c|c|c|}
\hline & Dummy for switching firms & $\log (1+$ Citations $)$ & $\log (1+$ Number of patents $)$ \\
\hline Variable & Model 1 & Model 2 & Model 3 \\
\hline Dummy for switching firms & & $\begin{array}{l}0.1134^{*} \\
(1.91)\end{array}$ & $\begin{array}{l}0.1424 * * \\
(2.15)\end{array}$ \\
\hline Dummy for post ASC & & $\begin{array}{l}-0.2504 * * * \\
(-8.02)\end{array}$ & $\begin{array}{l}-0.1251 * * * \\
(-3.48)\end{array}$ \\
\hline $\begin{array}{l}\text { Dummy for switching firms } \\
\times \text { Dummy for post ASC }\end{array}$ & & $\begin{array}{l}-0.2375 * * * \\
(-4.84)\end{array}$ & $\begin{array}{l}-0.2038 * * * \\
(-3.87)\end{array}$ \\
\hline $\mathrm{R} \& \mathrm{D}$-to-assets ratio & & $\begin{array}{l}0.3202 * * * \\
(5.72)\end{array}$ & $\begin{array}{l}0.5339 * * * \\
(8.14)\end{array}$ \\
\hline IRS attention & $\begin{array}{l}0.6712^{* * * *} \\
(21.68)\end{array}$ & & \\
\hline $\log ($ Size $)$ & $\begin{array}{l}0.0875^{* * *} \\
(16.23)\end{array}$ & $\begin{array}{l}0.1158 * * * \\
(9.42)\end{array}$ & $\begin{array}{l}0.1660 * * * \\
(9.61)\end{array}$ \\
\hline Cash-to-assets ratio & $\begin{array}{l}-0.1599 * * * \\
(-6.21)\end{array}$ & $\begin{array}{l}0.0692 * * * \\
(3.57)\end{array}$ & $\begin{array}{l}0.1012 * * * \\
(5.10)\end{array}$ \\
\hline Leverage & $\begin{array}{l}-0.0147 * \\
(-1.72)\end{array}$ & $\begin{array}{l}-0.0114 \\
(-1.33)\end{array}$ & $\begin{array}{l}-0.0099 \\
(-1.07)\end{array}$ \\
\hline ROA & & $\begin{array}{l}0.0066 \\
(1.04)\end{array}$ & $\begin{array}{l}-0.0135^{*} \\
(-1.77)\end{array}$ \\
\hline $\mathrm{M} / \mathrm{B}$ & & $\begin{array}{l}0.0020^{* *} \\
(2.43)\end{array}$ & $\begin{array}{l}0.0022 * * * \\
(2.60)\end{array}$ \\
\hline Sales growth & $\begin{array}{l}-0.0461 \\
(-1.17)\end{array}$ & & \\
\hline $\mathrm{K} / \mathrm{L}$ & $\begin{array}{l}-0.0878^{*} \\
(-1.84)\end{array}$ & $\begin{array}{l}-0.0276 \\
(-0.64)\end{array}$ & $\begin{array}{l}0.0094 \\
(0.16)\end{array}$ \\
\hline Average cash effective tax rates & $\begin{array}{l}0.1344 * * \\
(2.26)\end{array}$ & & \\
\hline $\begin{array}{l}\text { Volatility of cash effective } \\
\text { tax rates }\end{array}$ & $\begin{array}{l}0.0254 \\
(1.18)\end{array}$ & & \\
\hline Inverse Mills ratio & & $\begin{array}{l}-0.2955 \\
(-0.94)\end{array}$ & $\begin{array}{l}-1.1682 * * * \\
(-2.98)\end{array}$ \\
\hline Intercept & $\begin{array}{l}-0.8309^{* * *} \\
(-24.87)\end{array}$ & $\begin{array}{l}-0.2651 \\
(-1.00)\end{array}$ & $\begin{array}{l}-0.0890 \\
(-0.27)\end{array}$ \\
\hline Industry FE & Yes & Yes & Yes \\
\hline $\mathrm{N}$ & 11,024 & 11,024 & 11,024 \\
\hline Pseudo $\mathrm{R}^{2}$ or Adj. $\mathrm{R}^{2}$ & 0.091 & 0.113 & 0.181 \\
\hline
\end{tabular}

This table presents Heckman two-stage regression analysis for innovation performance using a sample of U.S. public firms adopting the OBRA or ASC method. Model 1 shows the results for the first stage, where a probit regression is used. The dependent variable is Dummy for switching firms, which is equal to one for an ASC user and zero for an OBRA user. IRS attention is a dummy variable that is equal to one for a firm with tax positions that incurred penalties, were increased, or were settled with the Internal Revenue Service during the year. Sales growth is this year's sales minus previous year's sales divided by previous year's sales. Average cash effective tax rates are the average of cash effective tax rates over the past three years, where the cash effective tax rate is equal to cash taxes paid divided by pre-tax earnings before special items. Volatility of cash effective tax rates is the standard deviation of cash effective tax rates over the past three years. Models 2 and 3 show the results for the second stage, where we estimate regressions of Citations and Number of patents over the period from 2003 through 2014 by including the inverse Mills ratio as an additional control that is estimated from the first-stage probit regression. Citations are the number of truncation-adjusted citations divided by the number of patents applied for by a firm. Number of patents is the number of patents applied for. Dummy for post ASC is equal to one for the years after 2006, and zero otherwise. Other variables are defined in Table 1. Numbers in parentheses are $t$-statistics computed using standard errors clustered by firm. There are fewer observations because of data availability. $* * *, * *$, and $*$ denote significance at the $1 \%, 5 \%$, and $10 \%$ levels, respectively. 
Table 4

Relation between R\&D tax credits and innovation performance for a sample of R\&D tax credit users from $10-\mathrm{K}$ reports.

\begin{tabular}{lcc}
\hline & $\log (1+$ Citations $)$ & $\log (1+$ Number of patents $)$ \\
\cline { 2 - 3 } Variable & Model 1 & Model 2 \\
\hline Dummy for switching firms & 0.1225 & 0.115 \\
Dummy for post ASC & $(1.64)$ & $(1.29)$ \\
& $-0.7129^{* * *}$ & 0.0020 \\
Dummy for switching firms & $(-12.08)$ & $(0.03)$ \\
$\quad \times$ Dummy for post ASC & $-0.2536^{* * *}$ & $-0.2180^{* * *}$ \\
R\&D-to-assets ratio & $(-4.48)$ & $(-3.69)$ \\
& $0.2361^{* * *}$ & $0.4663^{* * *}$ \\
Log(Size) & $(3.90)$ & $(6.90)$ \\
& $0.1550^{* * *}$ & $0.2860^{* * *}$ \\
Cash-to-assets ratio & $(11.80)$ & $(12.16)$ \\
& $0.0836^{* * *}$ & $0.0737^{* * *}$ \\
Leverage & $(5.31)$ & $(4.87)$ \\
& $-0.0409^{* *}$ & $-0.0497^{* *}$ \\
ROA & $(-2.15)$ & $(-2.36)$ \\
& 0.0149 & -0.0050 \\
M/B & $(0.95)$ & $(-0.33)$ \\
& $0.0027^{* *}$ & $0.0042^{* * *}$ \\
K/L & $(1.98)$ & $(2.90)$ \\
Intercept & $0.3612^{* *}$ & $0.5008^{*}$ \\
Industry FE & $(1.98)$ & $(1.95)$ \\
N & -0.3898 & $-1.3981^{* * *}$ \\
Adj. $\mathrm{R}^{2}$ & $(-1.09)$ & $(-3.95)$ \\
\hline Ths & Yes & Yes \\
& 9,104 & 9,104 \\
& 0.147 & 0.239 \\
\hline
\end{tabular}

This table presents regressions of innovation performance for a sample of U.S. firms that indicate in their 10-Ks they are an R\&D tax credit user. The dependent variable refers to the two measures of firm innovation performance over the period from 2003 through 2014, Citations in Model 1 and Number of patents in Model 2. Citations are the number of truncation-adjusted citations divided by the number of patents applied for by a firm. Number of patents is the number of patents applied for. Dummy for switching firms is equal to one for an ASC user and zero for an OBRA user. Dummy for post ASC is equal to one for the years after 2006, and zero otherwise. Other variables are defined in Table 1 . Numbers in parentheses are $t$-statistics computed using standard errors clustered by firm. $* * *, * *$, and $*$ denote significance at the $1 \%$, $5 \%$, and $10 \%$ levels, respectively. 
Table 5

Relation between R\&D tax credits and innovation performance for subsamples stratified by corporate governance measures.

Panel A: Sorted by E-index

\begin{tabular}{|c|c|c|c|c|}
\hline \multirow[b]{3}{*}{ Variable } & \multicolumn{2}{|c|}{$\log (1+$ Citations $)$} & \multicolumn{2}{|c|}{$\log (1+$ Number of patents $)$} \\
\hline & Low E-index & High E-index & Low E-index & High E-index \\
\hline & Model 1 & Model 2 & Model 3 & Model 4 \\
\hline \multirow[t]{2}{*}{ Dummy for switching firms } & 0.1712 & $0.5955 * * *$ & 0.1181 & $0.4975^{*}$ \\
\hline & (1.58) & (2.58) & $(0.79)$ & (1.68) \\
\hline \multirow[t]{2}{*}{ Dummy for post ASC } & $-0.6378 * * *$ & $-0.9240 * * *$ & -0.1396 & -0.3347 \\
\hline & $(-4.32)$ & $(-4.02)$ & $(-0.67)$ & $(-1.06)$ \\
\hline \multirow{2}{*}{$\begin{array}{l}\text { Dummy for switching firms } \\
\times \text { Dummy for post ASC }\end{array}$} & -0.1311 & $-0.6302 * * *$ & -0.1092 & $-0.6424 * *$ \\
\hline & $(-1.00)$ & $(-2.65)$ & $(-0.51)$ & $(-2.00)$ \\
\hline R\&D-to-assets ratio & $\begin{array}{l}2.1289 * * * \\
(3.34)\end{array}$ & $\begin{array}{l}3.3889 * * * \\
(3.04)\end{array}$ & $\begin{array}{l}5.7664 * * * \\
(5.69)\end{array}$ & $\begin{array}{l}4.9093 * * * \\
(3.19)\end{array}$ \\
\hline $\log ($ Size $)$ & $\begin{array}{l}0.1122 * * * \\
(3.80)\end{array}$ & $\begin{array}{l}0.1880 * * * \\
(3.02)\end{array}$ & $\begin{array}{l}0.4083 * * * \\
(6.50)\end{array}$ & $\begin{array}{l}0.4366 * * * \\
(4.08)\end{array}$ \\
\hline Cash-to-assets ratio & $\begin{array}{l}0.5010 * * * \\
(2.80)\end{array}$ & $\begin{array}{l}0.0979 \\
(0.73)\end{array}$ & $\begin{array}{l}0.5587 * * * \\
(2.61)\end{array}$ & $\begin{array}{l}0.2618^{*} \\
(1.67)\end{array}$ \\
\hline Leverage & $\begin{array}{l}0.0670 \\
(1.48)\end{array}$ & $\begin{array}{l}-0.0314 \\
(-0.41)\end{array}$ & $\begin{array}{l}0.1239^{*} \\
(1.88)\end{array}$ & $\begin{array}{l}-0.1860 * * \\
(-2.06)\end{array}$ \\
\hline ROA & $\begin{array}{l}0.2390 \\
(0.92)\end{array}$ & $\begin{array}{l}0.3337 \\
(0.85)\end{array}$ & $\begin{array}{l}0.8844 * * * \\
(2.29)\end{array}$ & $\begin{array}{l}0.4093 \\
(0.77)\end{array}$ \\
\hline $\mathrm{M} / \mathrm{B}$ & $\begin{array}{l}-0.0006 \\
(-0.11)\end{array}$ & $\begin{array}{l}0.0075 \\
(0.92)\end{array}$ & $\begin{array}{l}-0.0077 \\
(-1.06)\end{array}$ & $\begin{array}{l}0.0235^{* *} \\
(2.01)\end{array}$ \\
\hline $\mathrm{K} / \mathrm{L}$ & $\begin{array}{l}0.7445^{* *} \\
(2.52)\end{array}$ & $\begin{array}{l}-0.9245 \\
(-1.44)\end{array}$ & $\begin{array}{l}0.9027 \\
(1.55)\end{array}$ & $\begin{array}{l}-1.0517 \\
(-1.09)\end{array}$ \\
\hline Intercept & $\begin{array}{l}-1.0775 * * * \\
(-5.26)\end{array}$ & $\begin{array}{l}-2.3362 * * * \\
(-3.87)\end{array}$ & $\begin{array}{l}-3.3635 * * * \\
(-8.16)\end{array}$ & $\begin{array}{l}-4.6180^{* * * *} \\
(-4.46)\end{array}$ \\
\hline Industry FE & Yes & Yes & Yes & Yes \\
\hline $\mathrm{N}$ & 2,568 & 1,112 & 2,568 & 1,112 \\
\hline Adj. $R^{2}$ & 0.210 & 0.154 & 0.281 & 0.160 \\
\hline Wald test & & $\begin{array}{l}56.6384 * * * \\
{[0.000]}\end{array}$ & & $\begin{array}{l}65.1071 * * * \\
{[0.000]}\end{array}$ \\
\hline
\end{tabular}


Table 5 (continued)

\begin{tabular}{|c|c|c|c|c|}
\hline \multirow[b]{3}{*}{ Variable } & \multicolumn{2}{|c|}{$\log (1+$ Citations $)$} & \multicolumn{2}{|c|}{$\log (1+$ Number of patents $)$} \\
\hline & Low RGI & High RGI & Low RGI & High RGI \\
\hline & Model 1 & Model 2 & Model 3 & Model 4 \\
\hline Dummy for switching firms & $\begin{array}{l}0.1825 * * \\
(2.32)\end{array}$ & $\begin{array}{l}0.0673 \\
(0.72)\end{array}$ & $\begin{array}{l}0.2045 * * * \\
(2.37)\end{array}$ & $\begin{array}{l}0.0841 \\
(0.72)\end{array}$ \\
\hline Dummy for post ASC & $\begin{array}{l}-0.0282 \\
(-0.56)\end{array}$ & $\begin{array}{l}-0.2050 \text { *** } \\
(-3.31)\end{array}$ & $\begin{array}{l}0.0392 \\
(0.83)\end{array}$ & $\begin{array}{l}-0.0780 \\
(-1.22)\end{array}$ \\
\hline $\begin{array}{l}\text { Dummy for switching firms } \\
\times \text { Dummy for post ASC }\end{array}$ & $\begin{array}{l}-0.2121 * * * \\
(-2.81)\end{array}$ & $\begin{array}{l}-0.1259 \\
(-1.34)\end{array}$ & $\begin{array}{l}-0.1852 * * * \\
(-2.66)\end{array}$ & $\begin{array}{l}-0.1722^{*} \\
(-1.84)\end{array}$ \\
\hline R\&D-to-assets ratio & $\begin{array}{l}0.4663 * * * \\
(4.23)\end{array}$ & $\begin{array}{l}0.9053 * * * \\
(4.17)\end{array}$ & $\begin{array}{l}0.6142 * * * \\
(6.42)\end{array}$ & $\begin{array}{l}1.1918^{* * * *} \\
(5.47)\end{array}$ \\
\hline $\log ($ Size $)$ & $\begin{array}{l}0.2073 * * * \\
(11.77)^{2}\end{array}$ & $\begin{array}{l}0.1744 * * * \\
(8.74)\end{array}$ & $\begin{array}{l}0.3107 * * * \\
(12.98)\end{array}$ & $\begin{array}{l}0.3414 * * * \\
(9.76)\end{array}$ \\
\hline Cash-to-assets ratio & $\begin{array}{l}0.1231 * * * \\
(3.24)\end{array}$ & $\begin{array}{l}0.1677 * * * \\
(4.02)\end{array}$ & $\begin{array}{l}0.1036^{* * *} \\
(3.64)\end{array}$ & $\begin{array}{l}0.1310^{* * * *} \\
(4.15)\end{array}$ \\
\hline Leverage & $\begin{array}{l}-0.0496^{* *} \\
(-1.97)\end{array}$ & $\begin{array}{l}-0.0062 \\
(-0.19)\end{array}$ & $\begin{array}{l}-0.0747 * * * \\
(-2.81)\end{array}$ & $\begin{array}{l}-0.0027 \\
(-0.07)\end{array}$ \\
\hline ROA & $\begin{array}{l}0.1419^{* *} \\
(2.15)\end{array}$ & $\begin{array}{l}-0.0187 \\
(-0.21)\end{array}$ & $\begin{array}{l}0.0089 \\
(0.14)\end{array}$ & $\begin{array}{l}-0.0027 \\
(-0.02)\end{array}$ \\
\hline $\mathrm{M} / \mathrm{B}$ & $\begin{array}{l}0.0023 \\
(0.95)\end{array}$ & $\begin{array}{l}0.0056 \\
(1.57)\end{array}$ & $\begin{array}{l}0.0040^{*} \\
(1.82)\end{array}$ & $\begin{array}{l}0.0060^{*} \\
(1.83)\end{array}$ \\
\hline $\mathrm{K} / \mathrm{L}$ & $\begin{array}{l}0.2498 \\
(1.06)\end{array}$ & $\begin{array}{l}0.3966 \\
(1.36)\end{array}$ & $\begin{array}{l}0.7092 * * * \\
(2.61)\end{array}$ & $\begin{array}{l}0.4422 \\
(1.09)\end{array}$ \\
\hline Intercept & $\begin{array}{l}-1.2048^{* * *} \\
(-10.83)\end{array}$ & $\begin{array}{l}-1.3238^{* * * *} \\
(-10.12)\end{array}$ & $\begin{array}{l}-0.7662^{* * * *} \\
(-5.39)\end{array}$ & $\begin{array}{l}-2.3850^{* * *} \\
(-10.75)\end{array}$ \\
\hline Industry FE & Yes & Yes & Yes & Yes \\
\hline $\mathrm{N}$ & 3,874 & 2,684 & 3,874 & 2,684 \\
\hline Adj. $R^{2}$ & 0.117 & 0.108 & 0.231 & 0.272 \\
\hline Wald test & & $\begin{array}{c}2.6298^{*} \\
{[0.072]}\end{array}$ & & $\begin{array}{c}2.5648 * \\
{[0.077]}\end{array}$ \\
\hline
\end{tabular}

This table presents regressions of innovation performance for subsamples stratified by corporate governance measurers. In Panel A, the corporate governance measure is based on the E-index of Bebchuk, Cohen, and Ferrell (2009). High and low E-index firms are classified every year by the median of all U.S. listed firms with data available on the E-index. Firms with a higher E-index are viewed as having poorer governance. In Panel B, the corporate governance measure is based on a residual governance index (RGI) defined in Section 5.1, in spirit similar to Jenter and Lewellen (2015). Firms with a higher value of RGI show better governance. High and low RGI firms are classified every year by the median of all U.S. listed firms with data available on the RGI. The dependent variable is the two measures of firm innovation performance over the period from 2003 through 2014, Citations in Models 1 and 2 and Number of patents in Models 3 and 4. Citations are the number of truncation-adjusted citations divided by the number of patents applied for by a firm. Number of patents is the number of patents applied for. Dummy for switching firms is equal to one for an ASC user and zero for an OBRA user. Dummy for post ASC is equal to one for the years after 2006, and zero otherwise. Other variables are defined in Table 1. Numbers in parentheses are $t$-statistics computed using standard errors clustered by firm. The Wald test is used to test the significance of difference in coefficients on Dummy for switching firms $\times$ Dummy for post ASC between two subsamples ( $p$-value in brackets). ${ }^{* *}, * *$, and $*$ denote significance at the $1 \%, 5 \%$, and $10 \%$ levels, respectively. 
Table 6

Relation between R\&D tax credits and innovation performance for subsamples stratified by innovation diversity.

\begin{tabular}{|c|c|c|c|c|}
\hline \multirow[b]{3}{*}{ Variable } & \multicolumn{2}{|c|}{$\log (1+$ Citations $)$} & \multicolumn{2}{|c|}{$\log (1+$ Number of patents $)$} \\
\hline & Low $\mathrm{HHI}^{\text {innov }}$ & High $\mathrm{HHI}^{\text {innov }}$ & Low $\mathrm{HHI}^{\text {innov }}$ & High $\mathrm{HHI}^{\text {innov }}$ \\
\hline & Model 1 & Model 2 & Model 3 & Model 4 \\
\hline \multirow[t]{2}{*}{ Dummy for switching firms } & 0.0159 & 0.1235 & 0.0737 & -0.0292 \\
\hline & $(0.34)$ & $(1.21)$ & $(1.06)$ & $(-0.44)$ \\
\hline \multirow[t]{2}{*}{ Dummy for post ASC } & $-0.4305 * * *$ & $-0.7144 * * *$ & 0.0252 & 0.0142 \\
\hline & $(-7.67)$ & $(-7.19)$ & $(0.50)$ & $(0.31)$ \\
\hline \multirow{2}{*}{$\begin{array}{l}\text { Dummy for switching firms } \\
\times \text { Dummy for post ASC }\end{array}$} & $-0.3305 * * *$ & -0.1262 & $-0.2698 * * *$ & -0.0346 \\
\hline & $(-4.68)$ & $(-0.75)$ & $(-4.06)$ & $(-0.43)$ \\
\hline \multirow[t]{2}{*}{ R\&D-to-assets ratio } & -0.0156 & 0.0992 & $0.8213 * * *$ & $0.3868 * * *$ \\
\hline & $(-0.09)$ & $(0.36)$ & $(4.93)$ & $(3.84)$ \\
\hline \multirow[t]{2}{*}{$\log ($ Size $)$} & 0.0195 & 0.0042 & $0.3203 * * *$ & $0.0797 * * *$ \\
\hline & $(1.43)$ & $(0.14)$ & (17.03) & $(4.72)$ \\
\hline \multirow[t]{2}{*}{ Cash-to-assets ratio } & 0.0661 & 0.0508 & $0.0625^{*}$ & 0.0088 \\
\hline & $(1.41)$ & $(0.74)$ & $(1.67)$ & $(0.38)$ \\
\hline \multirow[t]{2}{*}{ Leverage } & 0.0083 & -0.0130 & 0.0035 & 0.0064 \\
\hline & $(0.53)$ & $(-0.35)$ & $(0.27)$ & $(0.30)$ \\
\hline \multirow[t]{2}{*}{ ROA } & 0.1550 & 0.0986 & 0.0467 & $0.1229 *$ \\
\hline & $(1.47)$ & $(0.75)$ & $(0.55)$ & $(1.79)$ \\
\hline \multirow[t]{2}{*}{$\mathrm{M} / \mathrm{B}$} & -0.0021 & -0.0036 & -0.0023 & -0.0008 \\
\hline & $(-0.84)$ & $(-0.54)$ & $(-0.95)$ & $(-0.26)$ \\
\hline \multirow[t]{2}{*}{$\mathrm{K} / \mathrm{L}$} & $-0.3455 * *$ & -0.3016 & -0.2073 & -0.0823 \\
\hline & $(-2.44)$ & $(-1.06)$ & $(-1.11)$ & $(-0.60)$ \\
\hline \multirow[t]{2}{*}{ Intercept } & $5.6215 * * *$ & $2.1663 * * *$ & 1.2286 & $1.0053 * * *$ \\
\hline & $(5.84)$ & (7.39) & $(0.97)$ & $(6.25)$ \\
\hline Industry FE & Yes & Yes & Yes & Yes \\
\hline $\mathrm{N}$ & 2,636 & 870 & 2,636 & 870 \\
\hline Adj. $R^{2}$ & 0.143 & 0.139 & 0.385 & 0.140 \\
\hline Wald test & & $\begin{array}{l}6.7168^{* * * *} \\
{[0.035]}\end{array}$ & & $\begin{array}{l}204.3607 * * * \\
{[0.000]}\end{array}$ \\
\hline
\end{tabular}

This table presents regressions of innovation performance for subsamples stratified by diversification of innovation activity. The procedure for computing innovation diversity, $H H I^{\text {innov }}$, is described in Section 5.2. Firms with a high (low)

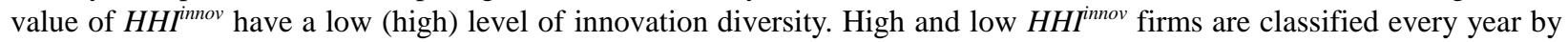
the median of all U.S. listed firms with data available on $H H I^{\text {innov }}$. The dependent variable refers to the two measures of firm innovation performance over the period from 2003 through 2014, Citations in Models 1 and 2 and Number of patents in Models 3 and 4. Citations are the number of truncation-adjusted citations divided by the number of patents applied for by a firm. Number of patents is the number of patents applied for. Dummy for switching firms is equal to one for an ASC user and zero for an OBRA user. Dummy for post ASC is equal to one for the years after 2006, and zero otherwise. Other variables are defined in Table 1 . Numbers in parentheses are $t$-statistics computed using standard errors clustered by firm. The Wald test is used to test the significance of difference in coefficients on Dummy for switching firms $\times$ Dummy for post ASC between two subsamples ( $p$-value in brackets). ***,**, and $*$ denote significance at the $1 \%, 5 \%$, and $10 \%$ levels, respectively. 
Table 7

Relation between R\&D tax credits and innovation performance: alternative measures of innovation performance.

\begin{tabular}{|c|c|c|c|c|c|c|}
\hline & Generality & Originality & Relative citations & Self-citations & Non-self-citations & Aggregate citations \\
\hline Variable & Model 1 & Model 2 & Model 3 & Model 4 & Model 5 & Model 6 \\
\hline \multirow[t]{2}{*}{ Dummy for switching firms } & $0.0125 * *$ & $0.0175^{*}$ & $1.4452 *$ & 11.0376 & $19.5479 * *$ & $29.2783^{*}$ \\
\hline & $(2.03)$ & $(1.81)$ & $(1.84)$ & $(1.55)$ & $(2.10)$ & $(1.81)$ \\
\hline \multirow[t]{2}{*}{ Dummy for post ASC } & $-0.0871 * * *$ & $-0.0840 * * *$ & $-3.8874 * * *$ & $-29.7120 * * *$ & $-46.5430 * * *$ & $-10.7563 * *$ \\
\hline & $(-20.25)$ & $(-10.57)$ & $(-9.32)$ & $(-7.04)$ & $(-9.38)$ & $(-2.03)$ \\
\hline \multirow{2}{*}{$\begin{array}{l}\text { Dummy for switching firms } \\
\times \text { Dummy for post ASC }\end{array}$} & $-0.0206 * * *$ & $-0.0171 * *$ & $-2.3080 * * *$ & $-20.8636 * * *$ & $-30.4761 * * *$ & $-54.4561 * * *$ \\
\hline & $(-4.00)$ & $(-2.24)$ & $(-4.68)$ & $(-4.59)$ & $(-5.21)$ & $(-5.33)$ \\
\hline \multirow[t]{2}{*}{ R\&D-to-assets ratio } & $0.0110 * * *$ & $0.0341 * * *$ & $1.6932 * * *$ & $17.3297 * * *$ & $19.3593 * * *$ & $38.8398 * * *$ \\
\hline & $(3.75)$ & $(5.56)$ & $(5.78)$ & $(5.45)$ & $(5.69)$ & $(6.07)$ \\
\hline \multirow[t]{2}{*}{$\log ($ Size $)$} & $0.0084 * * *$ & $0.0155^{* * *}$ & $1.6126 * * *$ & $15.2036 * * *$ & $19.2148 * * *$ & $34.3914 * * *$ \\
\hline & $(11.39)$ & $(9.62)$ & $(8.86)$ & $(8.36)$ & $(8.87)$ & $(8.84)$ \\
\hline \multirow[t]{2}{*}{ Cash-to-assets ratio } & $0.0021 * *$ & $0.0037 * *$ & $0.2420 * * *$ & $2.5684 * * *$ & $2.9560 * * *$ & $3.7757 * *$ \\
\hline & $(2.20)$ & $(2.17)$ & $(2.96)$ & $(2.95)$ & $(3.16)$ & $(2.22)$ \\
\hline \multirow[t]{2}{*}{ Leverage } & -0.0006 & -0.0012 & -0.1774 & $-3.1166^{*}$ & -1.4820 & -5.2343 \\
\hline & $(-0.44)$ & $(-0.48)$ & $(-1.09)$ & $(-1.81)$ & $(-0.78)$ & $(-1.49)$ \\
\hline \multirow[t]{2}{*}{ ROA } & 0.0009 & $0.0054 * * *$ & $-0.3745 * * *$ & $-3.0657 * * *$ & $-4.7412 * * *$ & $-7.1020 * * *$ \\
\hline & $(1.57)$ & $(4.31)$ & $(-4.88)$ & $(-3.84)$ & $(-5.23)$ & $(-4.45)$ \\
\hline \multirow[t]{2}{*}{$\mathrm{M} / \mathrm{B}$} & 0.0000 & $0.0003 *$ & 0.0119 & $0.1512 *$ & 0.1425 & $0.3080^{*}$ \\
\hline & $(0.36)$ & $(1.95)$ & $(1.52)$ & $(1.81)$ & $(1.51)$ & $(1.79)$ \\
\hline \multirow[t]{2}{*}{$\mathrm{K} / \mathrm{L}$} & 0.0041 & 0.0330 & 0.7769 & 17.9592 & 1.6314 & 17.1508 \\
\hline & $(0.40)$ & $(1.28)$ & $(0.36)$ & $(0.87)$ & $(0.07)$ & $(0.38)$ \\
\hline \multirow[t]{2}{*}{ Intercept } & 0.0102 & $-0.0620 * * *$ & $-6.5926 * * *$ & $-70.9798 * * *$ & $-70.7549 * * *$ & $-150.5127 * * *$ \\
\hline & $(0.84)$ & $(-3.83)$ & $(-4.86)$ & $(-5.44)$ & $(-3.62)$ & $(-4.69)$ \\
\hline Industry FE & Yes & Yes & Yes & Yes & Yes & Yes \\
\hline $\mathrm{N}$ & 15,092 & 15,092 & 15,092 & 15,092 & 15,092 & 15,092 \\
\hline Adj. $\mathrm{R}^{2}$ & 0.096 & 0.078 & 0.118 & 0.103 & 0.121 & 0.114 \\
\hline
\end{tabular}

This table presents regression analyses of six alternative measures of innovation performance over the period from 2003 through 2014 . Generality is the sum of squared ratios of forward-citations divided by the number of total forward citations that belong to the same International Patent Classification (IPC) code. Originality is measured using a similar formula but replacing forward-citations by backward-references. Relative citations are citations per patent divided by the median of citations per patent in the same IPC classification. Self-citations are the number of self-citations divided by the number of patents that a firm applied for, where self-citations are the citing of patents assigned by their inventors to the sample firms as the originating patents. Non-self-citations are the number of non-self-citations divided by the number of patents that a firm applied for. Aggregate citations are the aggregate citations of patents for a firm. Dummy for switching firms is equal to one for an ASC user and zero for an OBRA user. Dummy for post ASC is equal to one for the years after 2006, and zero otherwise. Other variables are defined in Table 1 . Numbers in parentheses are $t$-statistics computed using standard errors clustered by firm. $* * *, * *$, and $*$ denote significance at the $1 \%, 5 \%$, and $10 \%$ levels, respectively. 
Table 8

Relation between R\&D tax credits and firm performance and value.

\begin{tabular}{|c|c|c|}
\hline \multirow[b]{2}{*}{ Variable } & Operating performance & Firm value \\
\hline & Model 1 & Model 2 \\
\hline \multirow[t]{2}{*}{ Dummy for switching firms } & $0.0988 * * *$ & 0.8500 \\
\hline & $(5.89)$ & $(0.54)$ \\
\hline \multirow[t]{2}{*}{ Dummy for post ASC } & $0.0994 * * *$ & $15.5848 * * *$ \\
\hline & $(4.32)$ & $(2.75)$ \\
\hline \multirow{2}{*}{$\begin{array}{l}\text { Dummy for switching firms } \\
\times \text { Dummy for post ASC }\end{array}$} & $-0.1511 * * *$ & $-5.4290 * *$ \\
\hline & $(-5.66)$ & $(-1.98)$ \\
\hline \multirow[t]{2}{*}{ R\&D-to-assets ratio } & $-0.2285^{* * *}$ & $8.1187 *$ \\
\hline & $(-2.58)$ & $(1.65)$ \\
\hline \multirow[t]{2}{*}{$\log ($ Size $)$} & $0.0392 * * *$ & 0.1812 \\
\hline & $(6.62)$ & $(0.52)$ \\
\hline \multirow[t]{2}{*}{ Cash-to-assets ratio } & -0.0083 & $21.8320 * * *$ \\
\hline & $(-0.56)$ & $(8.80)$ \\
\hline \multirow[t]{2}{*}{ Leverage } & $-0.0089 * *$ & -0.4327 \\
\hline & $(-2.34)$ & $(-0.91)$ \\
\hline \multirow[t]{2}{*}{$\mathrm{K} / \mathrm{L}$} & 0.0734 & $-69.7859 * * *$ \\
\hline & $(1.20)$ & $(-8.15)$ \\
\hline \multirow[t]{2}{*}{ ROA } & $0.3760 * * *$ & $-14.1963 * * *$ \\
\hline & $(8.63)$ & $(-5.03)$ \\
\hline \multirow[t]{2}{*}{ Change in ROA } & $-0.0507 * * *$ & $8.2175^{*}$ \\
\hline & $(-3.06)$ & $(1.78)$ \\
\hline \multirow[t]{2}{*}{ Institutional ownership } & $0.0207 *$ & 0.8370 \\
\hline & $(1.67)$ & $(0.97)$ \\
\hline \multirow[t]{2}{*}{ Herfindahl-Hirschman index } & $0.1483 * * *$ & $4.4565^{* *}$ \\
\hline & $(3.77)$ & $(2.00)$ \\
\hline \multirow[t]{2}{*}{ Sales growth } & & -0.1535 \\
\hline & & $(-0.05)$ \\
\hline \multirow[t]{2}{*}{ Total factor productivity } & & $0.7039 * * *$ \\
\hline & & $(3.15)$ \\
\hline \multirow[t]{2}{*}{ Intercept } & $-0.3692 * * *$ & 17.1000 \\
\hline & $(-3.93)$ & $(1.32)$ \\
\hline Industry FE & Yes & Yes \\
\hline $\mathrm{N}$ & 15,092 & 9,762 \\
\hline Adj. $\mathrm{R}^{2}$ & 0.336 & 0.177 \\
\hline
\end{tabular}

This table presents regression analyses of firm performance and value over the period from 2003 through 2014. In Model 1, the dependent variable is the three-year average of operating performance over $t+1$ and $t+3$, where operating performance is measured by earnings before extraordinary items plus pre-tax $\mathrm{R} \& \mathrm{D}$ expenses divided by book assets. In Model 2, the dependent variable is Tobin's $Q$ in $t+1$, which is equal to the market value of equity plus the book value of debt and the book value of preferred equity minus inventories and deferred taxes, divided by book value of capital (proxied by property, plant, and equipment). Dummy for switching firms is equal to one for an ASC user and zero for an OBRA user. Dummy for post ASC is equal to one for the years after 2006, and zero otherwise. Change in ROA is the difference in ROA between years $t$ and $t-1$. Institutional ownership is the percentage of shares held by institutional investors. Herfindahl-Hirschman index is the sum of squared market shares over all firms in a three-digit SIC industry. Sales growth is the one-year sales growth rate. Total factor productivity is estimated as the regression residual of Cobb-Douglas production function, where we use firm revenues as the output and capital and number of employees as the inputs. Other variables are defined in Table 1 . Numbers in parentheses are $t$-statistics computed using standard errors clustered by firm. There are fewer observations in Model 2 because of data availability. $* * * * *$, and $*$ denote significance at the $1 \%, 5 \%$, and $10 \%$ levels, respectively. 
Table 9

Relation between R\&D tax credits and innovation performance for a sample of start-ups.

\begin{tabular}{|c|c|c|}
\hline \multirow[b]{2}{*}{ Variable } & $\log (1+$ Citations $)$ & $\log (1+$ Number of patents $)$ \\
\hline & Model 1 & Model 2 \\
\hline \multirow[t]{2}{*}{ Dummy for ASC start-ups } & $-0.4637 * * *$ & $-0.3499 * * *$ \\
\hline & $(-5.02)$ & $(-5.79)$ \\
\hline \multirow[t]{2}{*}{ Dummy for post ASC } & $-0.4837 * * *$ & $-0.2211 * * *$ \\
\hline & $(-5.93)$ & $(-3.67)$ \\
\hline \multirow{2}{*}{$\begin{array}{l}\text { Dummy for ASC start-ups } \\
\times \text { Dummy for post ASC }\end{array}$} & 0.5243 & 0.1923 \\
\hline & $(0.85)$ & $(0.51)$ \\
\hline \multirow[t]{2}{*}{ R\&D-to-assets ratio } & $0.1223 * *$ & $0.1702 * * *$ \\
\hline & $(2.06)$ & $(3.51)$ \\
\hline \multirow[t]{2}{*}{$\log ($ Size $)$} & $0.0584 * * *$ & $0.0621 * * *$ \\
\hline & $(5.42)$ & $(6.59)$ \\
\hline \multirow[t]{2}{*}{ Cash-to-assets ratio } & 0.0076 & 0.0074 \\
\hline & $(0.58)$ & $(0.80)$ \\
\hline \multirow[t]{2}{*}{ Leverage } & -0.0132 & $-0.0152 *$ \\
\hline & $(-1.08)$ & $(-1.71)$ \\
\hline \multirow[t]{2}{*}{ ROA } & 0.0061 & 0.0027 \\
\hline & $(1.43)$ & $(0.87)$ \\
\hline \multirow[t]{2}{*}{$\mathrm{M} / \mathrm{B}$} & 0.0004 & 0.0007 \\
\hline & $(0.64)$ & $(1.59)$ \\
\hline \multirow[t]{2}{*}{$\mathrm{K} / \mathrm{L}$} & -0.0038 & 0.0175 \\
\hline & $(-0.05)$ & $(0.23)$ \\
\hline \multirow[t]{2}{*}{ Intercept } & 0.0842 & -0.1494 \\
\hline & $(0.60)$ & $(-1.61)$ \\
\hline Industry FE & Yes & Yes \\
\hline $\mathrm{N}$ & 2,662 & 2,662 \\
\hline Adj. $R^{2}$ & 0.110 & 0.104 \\
\hline
\end{tabular}

This table presents regressions of innovation performance for a sample including two groups of start-ups that went public after 2002. Group A consists of start-ups that never applied for R\&D tax credits during our sample period, and Group B consists of start-ups that had no R\&D tax credits before 2007 but gained them through the ASC method. The dependent variable refers to the two measures of firm innovation performance over the period from 2003 through 2014, Citations in Model 1 and Number of patents in Model 2. Citations are the number of truncation-adjusted citations divided by the number of patents applied for by a firm. Number of patents is the number of patents applied for. Dummy for ASC start-ups is equal to one if a new start-up belongs to Group B, and zero if it belongs to Group A. Dummy for post ASC is equal to one for the years after 2006, and zero otherwise. Other variables are defined in Table 1. Numbers in parentheses are $t$-statistics computed using standard errors clustered by firm. ***, **, and * denote significance at the $1 \%, 5 \%$, and $10 \%$ levels, respectively. 
Table 10

Relation between R\&D tax credits and innovation performance for subsamples stratified by returns to scale.

\begin{tabular}{|c|c|c|c|c|}
\hline \multirow[b]{3}{*}{ Variable } & \multicolumn{2}{|c|}{$\log (1+$ Citations $)$} & \multicolumn{2}{|c|}{$\log (1+$ Number of patents $)$} \\
\hline & $\begin{array}{l}\text { Returns to scale } \\
>1\end{array}$ & $\begin{array}{l}\text { Returns to scale } \\
\leq 1\end{array}$ & $\begin{array}{l}\text { Returns to scale } \\
>1\end{array}$ & $\begin{array}{c}\text { Returns to scale } \\
\leq 1\end{array}$ \\
\hline & Model 1 & Model 2 & Model 3 & Model 4 \\
\hline Dummy for switching firms & $\begin{array}{l}0.0059 \\
(0.14)\end{array}$ & $\begin{array}{l}0.0731 * * \\
(2.14)\end{array}$ & $\begin{array}{l}0.0133 \\
(0.30)\end{array}$ & $\begin{array}{l}0.0881^{* * * *} \\
(2.53)\end{array}$ \\
\hline Dummy for post ASC & $\begin{array}{l}-0.1331 * * * \\
(-6.03)\end{array}$ & $\begin{array}{l}-0.0847 * * * \\
(-6.25)\end{array}$ & $\begin{array}{l}-0.0405^{*} \\
(-1.66)\end{array}$ & $\begin{array}{l}-0.0111 \\
(-0.77)\end{array}$ \\
\hline $\begin{array}{l}\text { Dummy for switching firms } \\
\times \text { Dummy for post ASC }\end{array}$ & $\begin{array}{l}-0.0976 * * * \\
(-3.15)\end{array}$ & $\begin{array}{l}-0.1096 * * * \\
(-4.21)\end{array}$ & $\begin{array}{l}-0.0627 * * \\
(-2.13)\end{array}$ & $\begin{array}{l}-0.1049 * * * \\
(-4.04)\end{array}$ \\
\hline R\&D-to-assets ratio & $\begin{array}{l}0.1059 * * * \\
(3.19)\end{array}$ & $\begin{array}{l}0.0614 * * * \\
(4.94)\end{array}$ & $\begin{array}{l}0.1949 * * * \\
(5.07)\end{array}$ & $\begin{array}{l}0.0802 * * * \\
(6.48)\end{array}$ \\
\hline $\log ($ Size $)$ & $\begin{array}{l}0.0506^{* * * *} \\
(7.09)\end{array}$ & $\begin{array}{l}0.0480 * * * \\
(9.25)\end{array}$ & $\begin{array}{l}0.0800 * * * \\
(7.80)\end{array}$ & $\begin{array}{l}0.0614 * * * \\
(9.44)\end{array}$ \\
\hline Cash-to-assets ratio & $\begin{array}{l}0.0398 * * * \\
(2.91)\end{array}$ & $\begin{array}{l}0.0034 \\
(0.84)\end{array}$ & $\begin{array}{l}0.0433 * * * \\
(3.29)\end{array}$ & $\begin{array}{l}0.0036 \\
(0.99)\end{array}$ \\
\hline Leverage & $\begin{array}{l}-0.0189 \\
(-1.59)\end{array}$ & $\begin{array}{l}0.0014 \\
(0.21)\end{array}$ & $\begin{array}{l}-0.0270 * * \\
(-2.16)\end{array}$ & $\begin{array}{l}-0.0002 \\
(-0.03)\end{array}$ \\
\hline ROA & $\begin{array}{l}0.0248 * * \\
(2.30)\end{array}$ & $\begin{array}{l}0.0057 \\
(1.21)\end{array}$ & $\begin{array}{l}0.0198 * \\
(1.78)\end{array}$ & $\begin{array}{l}-0.0026 \\
(-0.52)\end{array}$ \\
\hline $\mathrm{M} / \mathrm{B}$ & $\begin{array}{l}0.0025 * * * \\
(2.74)\end{array}$ & $\begin{array}{l}-0.0001 \\
(-0.16)\end{array}$ & $\begin{array}{l}0.0031 * * * \\
(3.31)\end{array}$ & $\begin{array}{l}0.0004 \\
(1.00)\end{array}$ \\
\hline $\mathrm{K} / \mathrm{L}$ & $\begin{array}{l}-0.0101 \\
(-0.09)\end{array}$ & $\begin{array}{l}-0.0026 \\
(-0.05)\end{array}$ & $\begin{array}{l}0.0501 \\
(0.33)\end{array}$ & $\begin{array}{l}0.0100 \\
(0.14)\end{array}$ \\
\hline Intercept & $\begin{array}{l}0.0349 \\
(0.22)\end{array}$ & $\begin{array}{l}-0.1704 * * \\
(-2.20)\end{array}$ & $\begin{array}{l}-0.3013 \\
(-1.56)\end{array}$ & $\begin{array}{l}-0.3162 * * * \\
(-3.91)\end{array}$ \\
\hline Industry FE & Yes & Yes & Yes & Yes \\
\hline $\mathrm{N}$ & 1,022 & 2,592 & 1,022 & 2,592 \\
\hline $\begin{array}{l}\text { Adj. } \mathrm{R}^{2} \\
\text { Wald test }\end{array}$ & 0.109 & $\begin{array}{c}0.092 \\
1.444 \\
{[0.707]}\end{array}$ & 0.161 & $\begin{array}{c}0.136 \\
1.587 \\
{[0.206]}\end{array}$ \\
\hline
\end{tabular}

This table presents regressions of innovation performance for subsamples stratified by returns to scale. We consider a Cobb-Douglas production function with inputs of labor, capital, and R\&D and with outputs of firm revenues. The production function is estimated for each firm using its time-series data. The returns to scale are equal to the sum of output elasticities of labor, capital, and R\&D from the estimated production function. The dependent variable refers to the two measures of firm innovation performance over the period from 2003 through 2014, Citations in Models 1 and 2 and Number of patents in Models 3 and 4. Citations are the number of truncation-adjusted citations divided by the number of patents applied for by a firm. Number of patents is the number of patents applied for. Dummy for switching firms is equal to one for an ASC user and zero for an OBRA user. Dummy for post ASC is equal to one for the years after 2006, and zero otherwise. Other variables are defined in Table 1. Numbers in parentheses are $t$-statistics computed using standard errors clustered by firm. The Wald test is used to test the significance of difference in coefficients on Dummy for switching firms $\times$ Dummy for post ASC between two subsamples ( $p$-value in brackets). ***, $* *$, and $*$ denote significance at the $1 \%, 5 \%$, and $10 \%$ levels, respectively. 
Table 11

Regression analysis for R\&D spillover effects.

\begin{tabular}{|c|c|c|}
\hline & $\begin{array}{c}\text { Missing } w_{i j} \text { is replaced } \\
\text { by zero }\end{array}$ & $\begin{array}{l}\text { Observation with missing } w_{i j} \\
\text { is dropped }\end{array}$ \\
\hline Variable & Model 1 & Model 2 \\
\hline \multirow[t]{2}{*}{ Dummy for switching firms } & $1.9627 *$ & $4.2663 * *$ \\
\hline & $(1.85)$ & $(2.55)$ \\
\hline \multirow[t]{2}{*}{ Dummy for post ASC } & $-5.4499 * * *$ & $-6.4645^{*}$ \\
\hline & $(-5.41)$ & $(-1.75)$ \\
\hline \multirow{2}{*}{$\begin{array}{l}\text { Dummy for switching firms } \\
\times \text { Dummy for post ASC }\end{array}$} & $-1.9652 *$ & 1.1524 \\
\hline & $(-1.89)$ & $(0.47)$ \\
\hline \multirow[t]{2}{*}{ R\&D-to-assets ratio } & $4.3907 * * *$ & $16.2410 * *$ \\
\hline & $(4.00)$ & $(2.48)$ \\
\hline \multirow[t]{2}{*}{$\log ($ Size $)$} & $2.0587 * * *$ & $1.6470 * * *$ \\
\hline & $(9.22)$ & $(2.75)$ \\
\hline \multirow[t]{2}{*}{ Cash-to-assets ratio } & 0.1020 & $-2.4739 * *$ \\
\hline & $(0.45)$ & $(-2.56)$ \\
\hline \multirow[t]{2}{*}{ Leverage } & $-0.7426 * *$ & -0.7168 \\
\hline & $(-2.29)$ & $(-0.87)$ \\
\hline \multirow[t]{2}{*}{ ROA } & $0.6326 * * *$ & $5.6224 * *$ \\
\hline & $(3.07)$ & $(2.43)$ \\
\hline \multirow[t]{2}{*}{$\mathrm{M} / \mathrm{B}$} & $0.0640 * * *$ & 0.1182 \\
\hline & $(2.93)$ & $(1.35)$ \\
\hline \multirow[t]{2}{*}{$\mathrm{K} / \mathrm{L}$} & $5.8609 *$ & 2.2118 \\
\hline & $(1.75)$ & $(0.25)$ \\
\hline \multirow[t]{2}{*}{ Intercept } & $-12.9914 * * *$ & -7.0690 \\
\hline & $(-7.41)$ & $(-0.77)$ \\
\hline Industry FE & Yes & Yes \\
\hline $\mathrm{N}$ & 15,092 & 4,549 \\
\hline Adj. $R^{2}$ & 0.146 & 0.484 \\
\hline
\end{tabular}

This table presents regressions of R\&D spillover effects over the period from 2003 through 2014. To estimate the R\&D spillover effect, we define technological proximity as an uncentered correlation coefficient of innovation activities of two firms $i$ and $j$ :

$$
S_{i} S_{j}^{\prime} / \sqrt{S_{i} S_{i}^{\prime}} \sqrt{S_{j} S_{j}^{\prime}}
$$

where $S_{i}=\left(S_{i, l}, \ldots, S_{i, k}\right)$ is a vector of innovation activity in technology classification $k$ for firm $i$. We use six technology classifications as in Hall, Jaffe, and Trajtenberg $(2001,2005)$ and measure innovation activity by the number of patents that a firm applied for at the U.S. Patent and Trademark Office. The R\&D spillover effect is estimated as:

$$
\sum_{j \neq i} w_{i j} C R D_{j t}
$$

where $w_{i j}$ is proximity between firms $i$ and $j$, and firm $j$ is in the same three-digit SIC industry as firm $i$; $C R D$ is firm $\mathrm{R} \& \mathrm{D}$ capital. Model 1 replaces the missing values of $w_{i j}$ with zero, and Model 2 drops the observation with missing $w_{i j}$. Dummy for switching firms is equal to one for an ASC user and zero for an OBRA user. Dummy for post ASC is equal to one for the years after 2006, and zero otherwise. Other variables are defined in Table 1. Numbers in parentheses are $t$-statistics computed using standard errors clustered by firm. $* * * * *$, and $*$ denote significance at the $1 \%, 5 \%$, and $10 \%$ levels, respectively. 
Table 12

Relation between R\&D tax credits and innovation performance: effect of the 1981 OBRA.

\begin{tabular}{|c|c|c|}
\hline \multirow[b]{2}{*}{ Variable } & $\log (1+$ Citations $)$ & $\log (1+$ Number of patents $)$ \\
\hline & Model 1 & Model 2 \\
\hline \multirow[t]{2}{*}{ Dummy for OBRA firms } & $0.0922 * *$ & 0.0253 \\
\hline & $(2.21)$ & $(0.78)$ \\
\hline \multirow[t]{2}{*}{ Dummy for post OBRA } & $-0.0882 * * *$ & $-0.0938 * * *$ \\
\hline & $(-8.12)$ & $(-10.66)$ \\
\hline \multirow{2}{*}{$\begin{array}{l}\text { Dummy for OBRA firms } \\
\times \text { Dummy for post OBRA }\end{array}$} & $0.0860 * *$ & $0.0655^{* *}$ \\
\hline & (2.19) & $(2.30)$ \\
\hline \multirow[t]{2}{*}{ R\&D-to-assets ratio } & $0.9695 * * *$ & $0.6226 * * *$ \\
\hline & $(16.06)$ & $(14.93)$ \\
\hline \multirow[t]{2}{*}{$\log ($ Size $)$} & $0.0935 * * *$ & $0.0912 * * *$ \\
\hline & $(21.53)$ & $(20.13)$ \\
\hline \multirow[t]{2}{*}{ Cash-to-assets ratio } & $0.1070 * * *$ & $0.0424 * * *$ \\
\hline & $(13.48)$ & $(9.04)$ \\
\hline \multirow[t]{2}{*}{ Leverage } & $-0.0227 * * *$ & $-0.0172 * * *$ \\
\hline & $(-11.94)$ & $(-11.22)$ \\
\hline \multirow[t]{2}{*}{ ROA } & $0.0726 * * *$ & $-0.0183^{*}$ \\
\hline & $(5.94)$ & $(-1.94)$ \\
\hline \multirow[t]{2}{*}{$\mathrm{M} / \mathrm{B}$} & $0.0059 * * *$ & $0.0040 * * *$ \\
\hline & $(8.47)$ & $(8.06)$ \\
\hline \multirow[t]{2}{*}{$\mathrm{K} / \mathrm{L}$} & $-0.0793 * * *$ & $-0.0553 * * *$ \\
\hline & $(-8.32)$ & $(-6.24)$ \\
\hline \multirow[t]{2}{*}{ Intercept } & $-0.1420 *$ & $-0.1948 * * *$ \\
\hline & $(-1.66)$ & $(-3.51)$ \\
\hline Industry FE & Yes & Yes \\
\hline $\mathrm{N}$ & 170,164 & 170,164 \\
\hline Adj. $R^{2}$ & 0.125 & 0.138 \\
\hline
\end{tabular}

This table investigates how the Omnibus Budget Reconciliation Act enacted in 1981 affected firm innovation performance. The dependent variable refers to the two measures of firm innovation performance over the period from 1974 through 2006, Citations in Model 1 and Number of patents in Model 2. Citations are the number of truncation-adjusted citations divided by the number of patents applied for by a firm. Number of patents is the number of patents applied for. Dummy for OBRA firms is equal to one if a firm does not gain R\&D tax credits before 1981 but gain R\&D tax credits through the OBRA in any year from 1981 through 2006, and zero if a firm does not obtain any R\&D tax credits from 1974 through 2006. Dummy for post OBRA is equal to one for the years after 1980, and zero otherwise. Other variables are defined in Table 1. Numbers in parentheses are $t$-statistics computed using standard errors clustered by firm. ${ }^{* *}, * *$, and $*$ denote significance at the $1 \%, 5 \%$, and $10 \%$ levels, respectively. 
Panel A: Innovation performance measured by citations

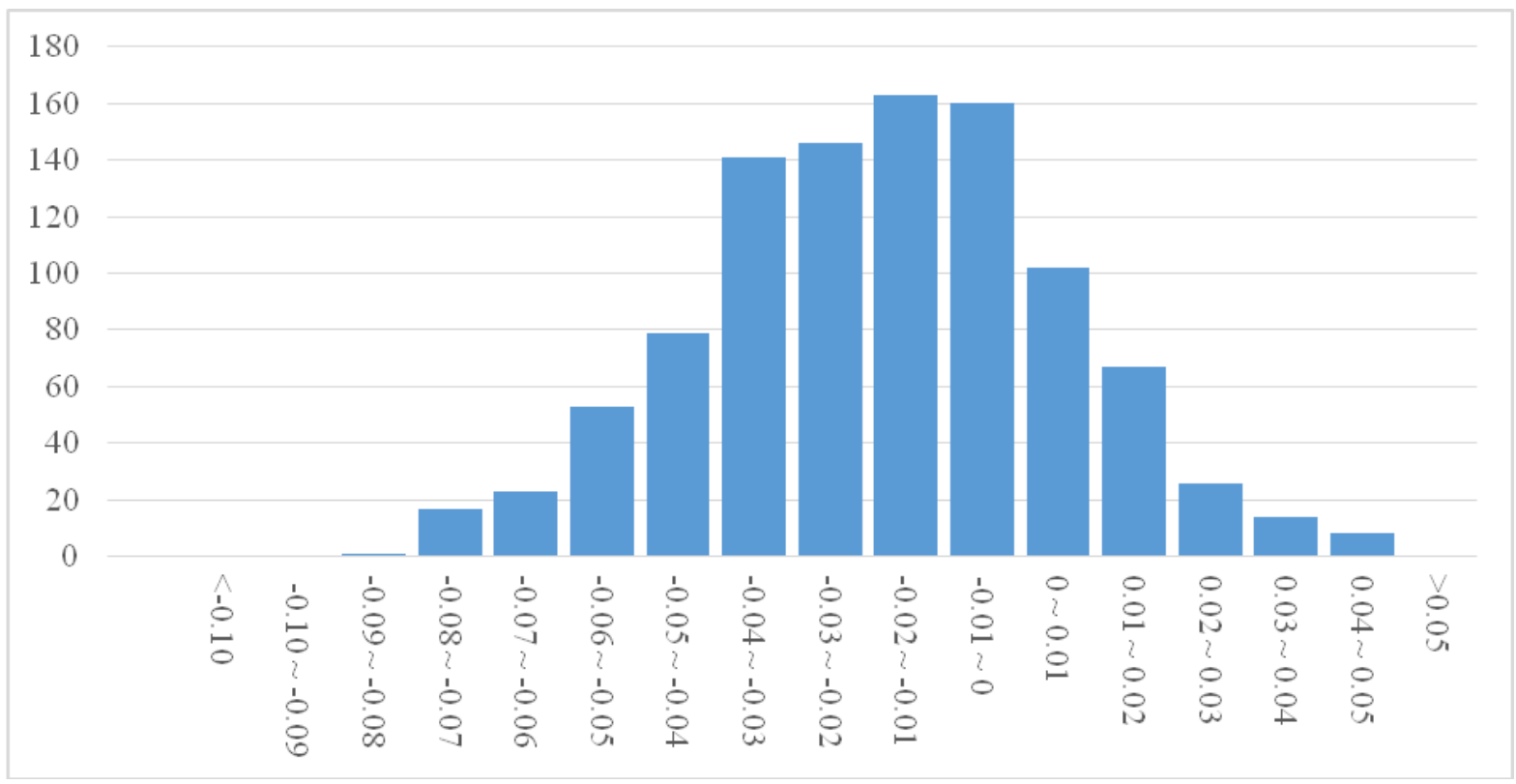

Panel B: Innovation performance measured by number of patents

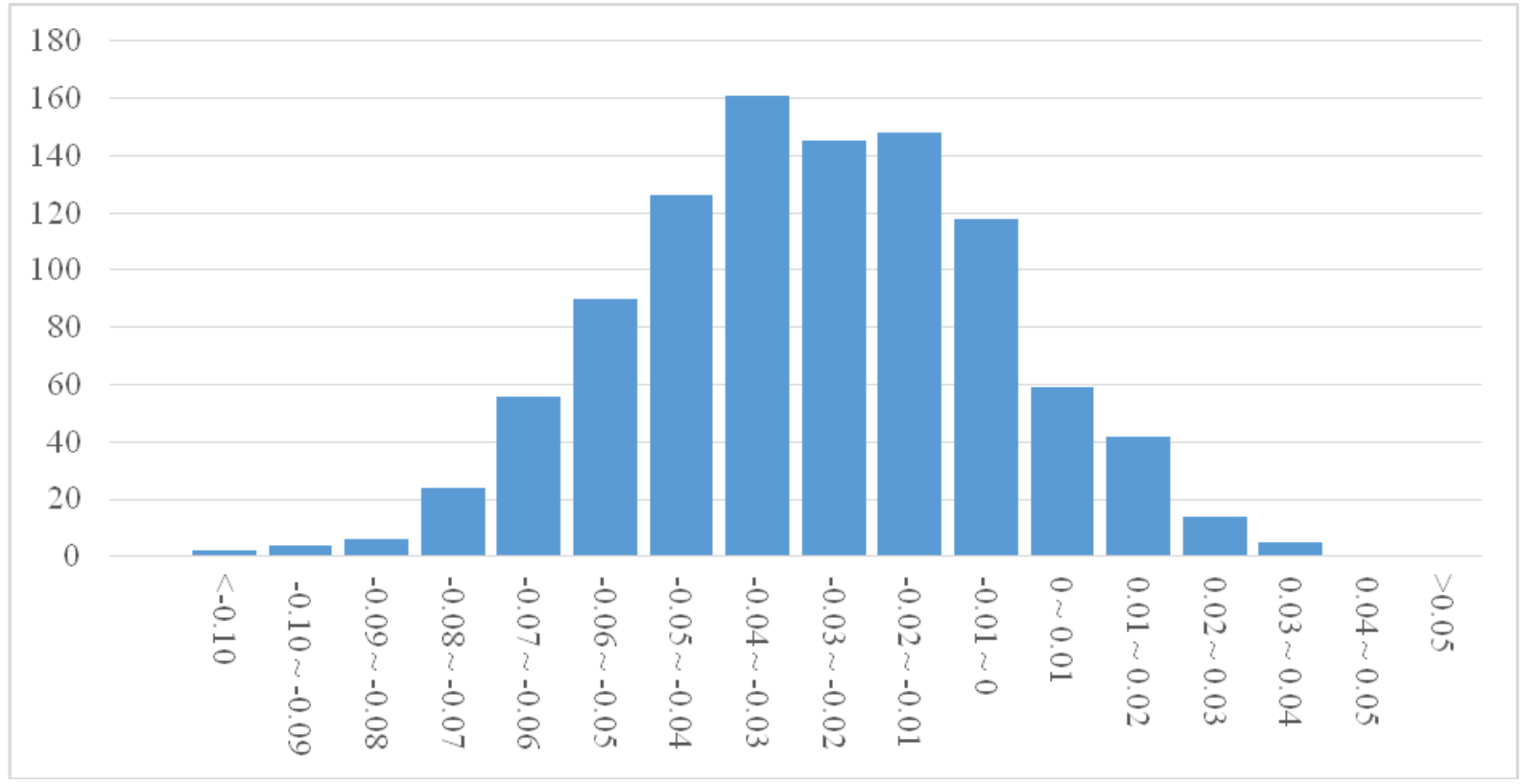

\section{Figure 1}

Distribution of coefficients on the interaction variable in regression equation (3): a placebo test.

This figure reports a placebo test for the distribution of coefficients on the interaction variable in the regression of innovation performance in Equation (3). Innovation performance is measured by Citations in Panel A and Number of patents in Panel B. Citations are the number of truncation-adjusted citations divided by the number of patents applied for by a firm. Number of patents is the number of patents applied for. We replace each ASC user with another firm randomly selected from among OBRA users (i.e., pseudo-ASC users). We re-run the regression for Equation (3) by replacing Dummy for switching firms by Dummy for switching placebos, which is equal to one for a pseudo-ASC user, and zero otherwise. We record the coefficient on the interaction variable, Dummy for switching placebos $\times$ Dummy for post ASC, where Dummy for post ASC is equal to one for the years after 2006, and zero otherwise. We repeat this procedure 1,000 times and hence obtain 1,000 estimated coefficients on the interaction variable. 
Internet Appendix for

"Tax policy and innovation performance:

Evidence from enactment of the Alternative Simplified Credit" 
Table A1

Relation between R\&D tax credits and R\&D spending.

\begin{tabular}{|c|c|c|}
\hline \multirow[b]{2}{*}{ Variable } & $2003-2010$ & $2005-2008$ \\
\hline & Model 1 & Model 2 \\
\hline \multirow[t]{2}{*}{ Dummy for switching firms } & -0.1321 & $-0.3222 *$ \\
\hline & $(-0.81)$ & $(-1.65)$ \\
\hline \multirow[t]{2}{*}{ Dummy for post ASC } & $-0.1587 * * *$ & $-0.1172 * * *$ \\
\hline & $(-6.84)$ & $(-4.96)$ \\
\hline \multirow{2}{*}{$\begin{array}{l}\text { Dummy for switching firms } \\
\times \text { Dummy for post ASC }\end{array}$} & $0.0662 *$ & $0.0718 * *$ \\
\hline & $(1.86)$ & $(2.05)$ \\
\hline \multirow[t]{2}{*}{$\log (1+$ Lagged R\&D) } & $0.7859 * * *$ & $0.6930 * * *$ \\
\hline & $(35.31)$ & $(18.77)$ \\
\hline \multirow[t]{2}{*}{$\log ($ Size $)$} & $0.1724 * * *$ & $0.1412 * * *$ \\
\hline & $(10.54)$ & $(7.35)$ \\
\hline \multirow[t]{2}{*}{ Internal funds } & $0.0002 * * *$ & $0.0001 * * *$ \\
\hline & (4.09) & $(3.01)$ \\
\hline \multirow{2}{*}{ Leverage } & -0.0045 & $-0.0081^{*}$ \\
\hline & $(-1.02)$ & $(-1.68)$ \\
\hline \multirow[t]{2}{*}{ Log(Real GDP) } & $0.0346 * * *$ & $0.0468 * * *$ \\
\hline & $(2.83)$ & $(3.46)$ \\
\hline \multirow{2}{*}{ Payout dummy } & -0.0032 & 0.0103 \\
\hline & $(-0.10)$ & $(0.28)$ \\
\hline \multirow[t]{2}{*}{$\log (1+$ Industry R\&D spending $)$} & $0.1029 * * *$ & $0.0844 * *$ \\
\hline & $(2.90)$ & $(2.08)$ \\
\hline \multirow[t]{2}{*}{ Marginal tax rate after interest } & -0.0552 & -0.0677 \\
\hline & $(-0.59)$ & $(-0.67)$ \\
\hline \multirow[t]{2}{*}{ Tobin's Q } & -0.0001 & -0.0002 \\
\hline & $(-1.00)$ & $(-1.52)$ \\
\hline \multirow[t]{2}{*}{ Intercept } & $-0.8133 * * *$ & $-0.4493 * * *$ \\
\hline & $(-5.34)$ & $(-2.79)$ \\
\hline $\mathrm{N}$ & 7,198 & 4,432 \\
\hline Wald $\chi^{2}$ & 3,205 & 1,191 \\
\hline
\end{tabular}

This table presents dynamic panel regressions of R\&D spending using a sample of U.S. public firms adopting the OBRA or ASC method. Coefficients are estimated using a system generalized method of moments (GMM) approach. The dependent variable is the logarithm of one plus R\&D expenditures over the periods from 2003 through 2010 in Model 1 and from 2005 through 2008 in Model 2. Dummy for switching firms is equal to one for an ASC user and zero for an OBRA user. Dummy for post ASC is equal to one for the years after 2006, and zero otherwise. Lagged $R \& D$ is one-year-lagged $\mathrm{R} \& \mathrm{D}$ expenditures. Size is book assets. Internal funds are the sum of income before extraordinary items, R\&D expenses, and depreciation divided by sales. Leverage is long-term debt divided by common equity. Real GDP is gross domestic product in 2004 trillions of dollars. Payout dummy is equal to one if a firm has a positive sum of dividends and share repurchases, and zero otherwise. Industry $R \& D$ spending is the average R\&D expenditure of the firm's industry by the Fama-French 48 industry classification. Marginal tax rate after interest is the marginal tax rate after interest deduction. Tobin's $Q$ is the market value of equity plus the book value of debt and the book value of preferred equity minus inventories and deferred taxes, divided by book value of capital (proxied by property, plant, and equipment). Numbers in parentheses are $t$-statistics computed using standard errors clustered by firm. $* * *, * *$, and $*$ denote significance at the $1 \%, 5 \%$, and $10 \%$ levels, respectively. 
Table A2

Relation between $R \& D$ tax credits and innovation performance using data on $R \& D$ tax credits reported in 10-Ks.

\begin{tabular}{|c|c|c|}
\hline & $\log (1+$ Citations $)$ & $\log (1+$ Number of patents $)$ \\
\hline Variable & Model 1 & Model 2 \\
\hline Dummy for switching firms & $\begin{array}{l}0.1520^{*} \\
(1.81)\end{array}$ & $\begin{array}{l}0.1062 \\
(1.47)\end{array}$ \\
\hline Dummy for post ASC & $\begin{array}{l}-0.0556 \\
(-0.84)\end{array}$ & $\begin{array}{l}0.0376 \\
(0.56)\end{array}$ \\
\hline $\begin{array}{l}\text { Dummy for switching firms } \\
\times \text { Dummy for post ASC }\end{array}$ & $\begin{array}{l}-0.2529 * * * \\
(-2.62)\end{array}$ & $\begin{array}{l}-0.1814^{*} \\
(-1.91)\end{array}$ \\
\hline R\&D-to-assets ratio & $\begin{array}{l}0.1115 \\
(1.36)\end{array}$ & $\begin{array}{l}0.1298^{*} \\
(1.80)\end{array}$ \\
\hline $\log ($ Size $)$ & $\begin{array}{l}0.0950 * * * \\
(3.96)\end{array}$ & $\begin{array}{l}0.1449 * * * \\
(5.54)\end{array}$ \\
\hline Cash-to-assets ratio & $\begin{array}{l}0.0449 \\
(1.55)\end{array}$ & $\begin{array}{l}0.0605^{* *} \\
(2.32)\end{array}$ \\
\hline Leverage & $\begin{array}{l}-0.0394 \\
(-1.12)\end{array}$ & $\begin{array}{l}-0.0648^{*} \\
(-1.68)\end{array}$ \\
\hline ROA & $\begin{array}{l}0.0169 \\
(0.27)\end{array}$ & $\begin{array}{l}-0.0328 \\
(-0.58)\end{array}$ \\
\hline $\mathrm{M} / \mathrm{B}$ & $\begin{array}{l}-0.0020 \\
(-0.76)\end{array}$ & $\begin{array}{l}0.0025 \\
(1.02)\end{array}$ \\
\hline $\mathrm{K} / \mathrm{L}$ & $\begin{array}{l}0.3149 \\
(1.26)\end{array}$ & $\begin{array}{l}0.4623^{*} \\
(1.68)\end{array}$ \\
\hline Intercept & $\begin{array}{l}-0.1215 \\
(-0.88)\end{array}$ & $\begin{array}{l}-0.4302 * * * \\
(-2.93)\end{array}$ \\
\hline Industry FE & Yes & Yes \\
\hline $\mathrm{N}$ & 697 & 697 \\
\hline Adj. $R^{2}$ & 0.187 & 0.330 \\
\hline
\end{tabular}

This table presents regressions of innovation performance for a sample of U.S. firms that report the amount of R\&D tax credits in 10-K reports. We compare their reported R\&D tax credits with our estimated R\&D tax credits. We identify a firm as an ASC user if its reported R\&D tax credits fall within the range between $\pm 20 \%$ of the estimated R\&D tax credits of the ASC regime and outside the range between $\pm 20 \%$ of the estimated R\&D tax credits of the OBRA regime. We use a similar approach to define an OBRA user. The dependent variable refers to the two measures of firm innovation performance over the period from 2003 through 2014, Citations in Model 1 and Number of patents in Model 2. Citations are the number of truncation-adjusted citations divided by the number of patents applied for by a firm. Number of patents is the number of patents applied for. Dummy for switching firms is equal to one for an ASC user and zero for an OBRA user. Dummy for post ASC is equal to one for the years after 2006, and zero otherwise. Other variables are defined in Table 1 . Numbers in parentheses are $t$-statistics computed using standard errors clustered by firm. $* * *, * *$, and $*$ denote significance at the $1 \%, 5 \%$, and $10 \%$ levels, respectively. 
Table A3

Relation between R\&D tax credits and innovation performance using an alternative definition of ASC users.

\begin{tabular}{|c|c|c|}
\hline \multirow[b]{2}{*}{ Variable } & $\log (1+$ Citations $)$ & $\log (1+$ Number of patents $)$ \\
\hline & Model 1 & Model 2 \\
\hline \multirow[t]{2}{*}{ Dummy for switching firms } & 0.0543 & -0.0150 \\
\hline & $(0.59)$ & $(-0.14)$ \\
\hline \multirow[t]{2}{*}{ Dummy for post ASC } & $-0.7086^{* * *}$ & $-0.3723 * * *$ \\
\hline & $(-19.49)$ & $(-9.99)$ \\
\hline \multirow{2}{*}{$\begin{array}{l}\text { Dummy for switching firms } \\
\times \text { Dummy for post ASC }\end{array}$} & $-0.2962 * * *$ & $-0.2483 * * *$ \\
\hline & $(-4.24)$ & $(-3.83)$ \\
\hline \multirow[t]{2}{*}{ R\&D-to-assets ratio } & $0.1411 * * *$ & $0.2212 * * *$ \\
\hline & (5.02) & $(7.86)$ \\
\hline \multirow[t]{2}{*}{$\log ($ Size $)$} & $0.1087 * * *$ & $0.1750 * * *$ \\
\hline & (12.54) & (12.84) \\
\hline \multirow[t]{2}{*}{ Cash-to-assets ratio } & $0.0279 * * *$ & $0.0230 * * *$ \\
\hline & $(3.20)$ & (2.98) \\
\hline \multirow[t]{2}{*}{ Leverage } & -0.0154 & $-0.0248^{*}$ \\
\hline & $(-1.13)$ & $(-1.69)$ \\
\hline \multirow[t]{2}{*}{ ROA } & $0.0107 *$ & -0.0100 \\
\hline & (1.75) & $(-1.57)$ \\
\hline \multirow[t]{2}{*}{$\mathrm{M} / \mathrm{B}$} & $0.0016^{* *}$ & $0.0024 * * *$ \\
\hline & (2.07) & (3.35) \\
\hline \multirow[t]{2}{*}{$\mathrm{K} / \mathrm{L}$} & 0.0676 & 0.1354 \\
\hline & $(0.61)$ & $(0.96)$ \\
\hline \multirow[t]{2}{*}{ Intercept } & -0.0909 & $-0.7569 * * *$ \\
\hline & $(-0.30)$ & $(-4.40)$ \\
\hline Industry FE & Yes & Yes \\
\hline $\mathrm{N}$ & 12,914 & 12,914 \\
\hline Adj. $R^{2}$ & 0.101 & 0.158 \\
\hline
\end{tabular}

This table presents regressions of innovation performance using an alternative definition of ASC users. The dependent variable refers to the two measures of firm innovation performance over the period from 2003 through 2014, Citations in Model 1 and Number of patents in Model 2. Citations are the number of truncation-adjusted citations divided by the number of patents applied for by a firm. Number of patents is the number of patents applied for. We redefine the ASC user as a firm that used the OBRA method before 2009 but switched to the ASC method in 2009 or 2010 and the OBRA user as a firm that kept using OBRA throughout the sample period. Dummy for switching firms is equal to one for an ASC user and zero for an OBRA user. Dummy for post ASC is redefined to be equal to one for the years after 2008 , and zero otherwise. Other variables are defined in Table 1. Numbers in parentheses are $t$-statistics computed using standard errors clustered by firm. ***, **, and * denote significance at the $1 \%$, 5\%, and $10 \%$ levels, respectively. 
Table A4

Relation between R\&D tax credits and innovation performance using a propensity score matched sample.

\begin{tabular}{|c|c|c|c|c|}
\hline \multirow[b]{3}{*}{ Variable } & \multicolumn{2}{|c|}{ Nearest neighbor matching } & \multicolumn{2}{|c|}{ Caliper matching } \\
\hline & $\log (1+$ Citations $)$ & $\begin{array}{c}\log (1+\text { Number } \\
\text { of patents })\end{array}$ & $\log (1+$ Citations $)$ & $\begin{array}{c}\log (1+\text { Number } \\
\text { of patents })\end{array}$ \\
\hline & Model 1 & Model 2 & Model 3 & Model 4 \\
\hline Dummy for switching firms & $\begin{array}{l}0.1939 * * \\
(2.13)\end{array}$ & $\begin{array}{l}0.2625^{* *} \\
(2.38)\end{array}$ & $\begin{array}{l}0.0494 \\
(0.71)\end{array}$ & $\begin{array}{l}0.1348 \\
(1.59)\end{array}$ \\
\hline Dummy for post ASC & $\begin{array}{l}-0.7694 * * * \\
(-11.04)\end{array}$ & $\begin{array}{l}-0.5884 * * * \\
(-7.66)\end{array}$ & $\begin{array}{l}-0.9128 * * * \\
(-19.74)\end{array}$ & $\begin{array}{l}-0.5404 * * * \\
(-10.60)\end{array}$ \\
\hline $\begin{array}{l}\text { Dummy for switching firms } \\
\times \text { Dummy for post ASC }\end{array}$ & $\begin{array}{l}-0.1436^{* *} \\
(-2.46)\end{array}$ & $\begin{array}{l}-0.1211 * * \\
(-1.99)\end{array}$ & $\begin{array}{l}-0.1440 * * * \\
(-2.94)\end{array}$ & $\begin{array}{l}-0.1833 * * * \\
(-3.37)\end{array}$ \\
\hline $\mathrm{R} \& \mathrm{D}$-to-assets ratio & $\begin{array}{l}0.5922 * * * \\
(3.72)\end{array}$ & $\begin{array}{l}0.9131 * * * \\
(4.83)\end{array}$ & $\begin{array}{l}0.1754 * * * \\
(5.13)\end{array}$ & $\begin{array}{l}0.2619 * * * \\
(7.43)\end{array}$ \\
\hline $\log ($ Size $)$ & $\begin{array}{l}0.0874 * * * \\
(5.71)\end{array}$ & $\begin{array}{l}0.1705 * * * \\
(6.07)\end{array}$ & $\begin{array}{l}0.1127 * * * \\
(11.33)\end{array}$ & $\begin{array}{l}0.1844 * * * \\
(11.02)\end{array}$ \\
\hline Cash-to-assets ratio & $\begin{array}{l}0.1265^{* *} \\
(2.34)\end{array}$ & $\begin{array}{l}0.1022 * \\
(1.70)\end{array}$ & $\begin{array}{l}0.0349 * * * \\
(2.85)\end{array}$ & $\begin{array}{l}0.0341 * * * \\
(2.99)\end{array}$ \\
\hline Leverage & $\begin{array}{l}0.0158 \\
(0.73)\end{array}$ & $\begin{array}{l}0.0392 \\
(1.36)\end{array}$ & $\begin{array}{l}-0.0166 \\
(-1.14)\end{array}$ & $\begin{array}{l}-0.0138 \\
(-0.79)\end{array}$ \\
\hline ROA & $\begin{array}{l}0.0320 \\
(1.00)\end{array}$ & $\begin{array}{l}-0.0110 \\
(-0.25)\end{array}$ & $\begin{array}{l}0.0245^{* * * *} \\
(3.40)\end{array}$ & $\begin{array}{l}0.0002 \\
(0.03)\end{array}$ \\
\hline $\mathrm{M} / \mathrm{B}$ & $\begin{array}{l}0.0027 \\
(0.78)\end{array}$ & $\begin{array}{l}0.0022 \\
(0.49)\end{array}$ & $\begin{array}{l}0.0007 \\
(0.79)\end{array}$ & $\begin{array}{l}0.0016 * \\
(1.72)\end{array}$ \\
\hline $\mathrm{K} / \mathrm{L}$ & $\begin{array}{l}-0.1838 \\
(-0.73)\end{array}$ & $\begin{array}{l}-0.3316 \\
(-0.95)\end{array}$ & $\begin{array}{l}0.0328 \\
(0.27)\end{array}$ & $\begin{array}{l}0.0988 \\
(0.60)\end{array}$ \\
\hline Intercept & $\begin{array}{l}-0.2326 * * * \\
(-2.90)\end{array}$ & $\begin{array}{l}-0.7504 * * * \\
(-5.93)\end{array}$ & $\begin{array}{l}0.5330 \\
(0.54)\end{array}$ & $\begin{array}{l}-0.5319 * \\
(-1.77)\end{array}$ \\
\hline Industry FE & Yes & Yes & Yes & Yes \\
\hline $\mathrm{N}$ & 10,705 & 10,705 & 10,705 & 10,705 \\
\hline Adj. $R^{2}$ & 0.128 & 0.191 & 0.102 & 0.178 \\
\hline
\end{tabular}

This table presents regressions of innovation performance using a propensity score matched sample. For each year from 2007 through 2010, we perform a probit regression where the dependent variable is equal to one for the ASC users and zero for the OBRA users, and the independent variables include $\log (\mathrm{Size})$, Cash-to-assets ratio, Leverage, PPE-to-assets ratio, and Sales growth. The propensity score is calculated using the estimated coefficients and realizations of the corresponding independent variables for each firm. In Models 1 and 2, each ASC user is matched to an OBRA user with the closest propensity score. We use an alternative matching approach in Models 3 and 4 by first forming a matched group of OBRA users within a 0.001 caliper of the ASC user's propensity score and then taking the average of the matched group for each ASC user. The dependent variable refers to the two measures of firm innovation performance over the period from 2003 through 2014. Citations are the number of truncation-adjusted citations divided by the number of patents applied for by a firm. Number of patents is the number of patents applied for. Dummy for switching firms is equal to one for an ASC user and zero for an OBRA user. Dummy for post ASC is equal to one for the years after 2006, and zero otherwise. Other variables are defined in Table 1. Numbers in parentheses are $t$-statistics computed using standard errors clustered by firm. $* * *, * *$, and $*$ denote significance at the $1 \%, 5 \%$, and $10 \%$ levels, respectively. 
Table A5

Relation between R\&D tax credits and innovation performance after accounting for another self-selection issue.

\begin{tabular}{|c|c|c|c|}
\hline & $\begin{array}{c}\text { Dummy for } \\
\text { R\&D tax credit users }\end{array}$ & $\log (1+$ Citations $)$ & $\log (1+$ Number of patents $)$ \\
\hline Variable & Model 1 & Model 2 & Model 3 \\
\hline Dummy for switching firms & & $\begin{array}{l}0.1107^{*} \\
(1.87)\end{array}$ & $\begin{array}{l}0.1434 * * \\
(2.17)\end{array}$ \\
\hline Dummy for post ASC & & $\begin{array}{l}-0.2298 * * * \\
(-7.38)\end{array}$ & $\begin{array}{l}-0.1120 * * * \\
(-2.99)\end{array}$ \\
\hline $\begin{array}{l}\text { Dummy for switching firms } \\
\times \text { Dummy for post ASC }\end{array}$ & & $\begin{array}{l}-0.2253 * * * \\
(-4.65)\end{array}$ & $\begin{array}{l}-0.1975^{* * *} \\
(-3.80)\end{array}$ \\
\hline R\&D-to-assets ratio & & $\begin{array}{l}0.3258 * * * \\
(5.79)\end{array}$ & $\begin{array}{l}0.5191 * * * \\
(8.02)\end{array}$ \\
\hline IRS attention & $\begin{array}{l}0.1856^{* * *} \\
(10.28)\end{array}$ & & \\
\hline $\log ($ Size $)$ & $\begin{array}{l}0.0682 * * * \\
(18.94)\end{array}$ & $\begin{array}{l}0.1293 * * * \\
(9.77)\end{array}$ & $\begin{array}{l}0.1567 * * * \\
(8.89)\end{array}$ \\
\hline Cash-to-assets ratio & $\begin{array}{l}0.1600 * * * \\
(10.09)\end{array}$ & $\begin{array}{l}0.0749 * * \\
(2.50)\end{array}$ & $\begin{array}{l}-0.0126 \\
(-0.32)\end{array}$ \\
\hline Leverage & $\begin{array}{l}-0.0329 * * * \\
(-7.85)\end{array}$ & $\begin{array}{l}-0.0150 \\
(-1.50)\end{array}$ & $\begin{array}{l}0.0044 \\
(0.37)\end{array}$ \\
\hline ROA & & $\begin{array}{l}0.0053 \\
(0.85)\end{array}$ & $\begin{array}{l}-0.0114 \\
(-1.55)\end{array}$ \\
\hline $\mathrm{M} / \mathrm{B}$ & & $\begin{array}{l}0.0020 * * \\
(2.42)\end{array}$ & $\begin{array}{l}0.0023^{* * * *} \\
(2.62)\end{array}$ \\
\hline Sales growth & $\begin{array}{l}-0.0773 * * * \\
(-3.54)\end{array}$ & & \\
\hline $\mathrm{K} / \mathrm{L}$ & $\begin{array}{l}-0.4265 * * * \\
(-18.39)\end{array}$ & $\begin{array}{l}-0.0497 \\
(-1.22)\end{array}$ & $\begin{array}{l}0.0855 \\
(1.45)\end{array}$ \\
\hline Average cash effective tax rates & $\begin{array}{l}-0.0821 * * \\
(-2.30)\end{array}$ & & \\
\hline $\begin{array}{l}\text { Volatility of cash effective } \\
\text { Tax rates }\end{array}$ & $\begin{array}{l}0.0263^{* *} \\
(2.12)\end{array}$ & & \\
\hline Inverse Mills ratio & & $\begin{array}{l}0.8546 \\
(0.59)\end{array}$ & $\begin{array}{l}-4.9724 * * \\
(-2.32)\end{array}$ \\
\hline Intercept & $\begin{array}{l}-1.7256 * * * \\
(-75.69)\end{array}$ & $\begin{array}{l}-1.1551 \\
(-1.01)\end{array}$ & $\begin{array}{l}3.0007 * \\
(1.78)\end{array}$ \\
\hline Industry FE & Yes & Yes & Yes \\
\hline $\mathrm{N}$ & 52,574 & 11,024 & 11,024 \\
\hline Pseudo $\mathrm{R}^{2}$ or Adj. $\mathrm{R}^{2}$ & 0.045 & 0.113 & 0.180 \\
\hline
\end{tabular}

This table presents Heckman two-stage regression analysis for innovation performance to account for a potential self-selection bias arising from firm voluntary decision about whether to use R\&D tax credits. Model 1 shows the results for the first stage, where a probit regression is used. The dependent variable is Dummy for $R \& D$ tax credit users, which is equal to one if a firm uses the OBRA method before 2007 and the OBRA or ASC method over the period from 2007 through 2010, and zero otherwise. Explanatory variables are defined in Table 3. Models 2 and 3 shows the results for the second stage, where we estimate regressions of Citations and Number of patents over the period from 2003 through 2014 by including the inverse Mills ratio as an additional control that is estimated from the first-stage probit regression. Citations are the number of truncation-adjusted citations divided by the number of patents applied for by a firm. Number of patents is the number of patents applied for. Dummy for switching firms is equal to one for an ASC user and zero for an OBRA user. Dummy for post ASC is equal to one for the years after 2006, and zero otherwise. Other variables are defined in Table 1 . Numbers in parentheses are $t$-statistics computed using standard errors clustered by firm. $* * * * *$, and $*$ denote significance at the $1 \%, 5 \%$, and $10 \%$ levels, respectively. 